\title{
Yaratıcılık ve Yaratıcı Düşünme: Tüm Boyut ve Paydaşlarıyla Kapsayıcı Bir Derleme Çalışması
}

\author{
DOI: 10.26466/opus.662721
}

*

\author{
Etem Yeșilyurt * \\ * Doç. Dr., Akdeniz Üniversitesi, Eğitim Fakültesi, Konyaaltı / Antalya / Türkiye \\ E-Posta: etemyesilyurt@akdeniz.edu.tr \\ ORCID: $\underline{0000-0002-7340-7536}$
}

\section{$\ddot{O} z$}

Yaratıcıllı ve yaratıcı düşünme doğuştan getirilen, olumlu çevre şartları altında geliştirilen, olumsuz çevre şartları altında durağanlaşan ya da körelen bir beceri olarak kabul edilmektedir. Eğitimle geliştirilebilen yaratıcllı ve yaratıcı düşünme becerisi, ülkemizde eğitimin genel amaçları arasında yerini almıştır. Bireylerin yaratıcılıkları ve yaratıcı düşünme becerilerinin gelişmesini başta aile olmak üzere sosyal ve fiziksel çevre, okul, öğretim programları, öğretmen vb. birçok faktör etkilemektedir. Derleme niteliği taşıyan bu çalışma, yaratıcılık ve yaratıcı düşünmeyle ilgili alanyazında yer alan ve ulaşılan kaynaklardaki temel bilgileri derleyerek bir çalışma içerisinde sunmak amacıyla yapılmıştır. Çalışma kapsamında öncelikle yaratıcılık kavramına ilişkin tanımlara yer verilmiş ve bu tanımlara kaynaklık eden yaklaşımlar incelenmiştir. Daha sonra yaratıcı bireyin özelliklerine, yaratıcılıkla ilgili yanlış anlaşılmalara, yaratıcılı̆̆ın boyutları ve aşamalarına yer verilmiştir. Zekâ, yaş, beyin, ıraksak düşünme ve hayal gücü kavramlar ile yaratıcılık arasındaki ilişkiye değinildikten sonra yaratıcilı̆̆ı engelleyen faktörler ele alınmıştır. Öte yandan düşünme ve düşünce kavramlarının tanımlarına yer verilmiş, üst düzey düşünme becerilerinden olan yaratıcı düşünme hakkında bilgi sunulmuştur. Bunlara ilaveten yaratıcı düşünmenin gelişimini kolaylaştıran yollara, öğrenme-öğretme ortamlarına, öğretmen özelliklerine değinilmiş, yaratıcıllğ̆ geliştirmek ve desteklemek için ebeveyn ve çevreye düşen görevler açıklanmıştır. "Yaratıcılık ve yaratıcı düşünme el kitabı" niteliğinde olan bu çalışmanın alanyazına, bireylerin yaratıcllıklarına ve yaratıcı düşünme becerilerinin gelişimine katkı sağlayacağı umulmaktadır.

Anahtar Kelimeler: Yaratıcılık, düşünme, yaratıcı düşünme, üst düzey düşünme. 


\title{
Creativity and Creative Thinking: A Comprehensive Review Study with All Dimension and Stakeholders
}

\begin{abstract}
Creativity and creative thinking are considered as innate skills developed under positive environmental conditions, stagnating or dulling under negative environmental conditions. Creativity and creative thinking skills, which can be improved with education, have taken their place among the general aims of education in our country. Many factors especially such as family and social and physical environment, school, curriculum, teacher etc. affect the development of individuals' creativity and creative thinking skills. This review study was conducted in order to compile and present the basic information in the literature about creativity and creative thinking. First of all, definitions related to creativity concept were given and the approaches that originated from these definitions were examined in the scope of the study. Then, features of creative individual, misunderstandings about creativity, dimensions and stages of creativity were given. The factors that prevent creativity were discussed after mentioning the relationship between the concepts of intelligence, age, brain, divergent thinking and imagination. On the other hand, definitions of thinking and thought concepts are given and information about creative thinking which is one of the high level thinking skills is presented. In addition, the ways of facilitating the development of creative thinking, learning-teaching environments, teacher characteristics are mentioned, and the duties of parents and the environment to develop and support creativity are explained. It is hoped that this study which can be considered as "a brief handbook of creativity and creative thinking" will contribute to the literature, the creativity of individuals and the development of creative thinking skills.
\end{abstract}

Keywords: Creativity, thinking, creative thinking, high level thinking. 


\section{Giriş}

Günümüz dünyasında toplumları veya devletleri, diğer toplum ve devletlerden ayıran temel kavramlar, gelişim ve kalkınmadır. Başta ekonomik, insani, sosyal, teknolojik vb. olmak üzere gelişim ve kalkınmanın birçok boyutu vardır. Elbette ki her çeşit kalınmanın temel besin kaynağı, eğitimdir. Eğitim ve eğitim sistemlerinin bu rolleri yerine getirmesi bilgi, düşünce, ürün vb. konularda yaratıcı olan ve düşünen bireyler yetiştirmesiyle yakından ilgilidir.

İnsanoğlunu diğer canlılardan ayıran en temel yönlerinden birisi olan yaratıcilık ve yaratıcı düşünme becerisi, ilkçağ düşünür ve felsefecilerinden günümüz bilim insanlarına kadar her dönemde ilgi gören ve gizemini koruyan bir konudur (Eker ve Sak, 2016). Yaratıcilikla ilgili fikirlerin Platon'a kadar uzandığı anlaşılmaktadır (Maba, 2019). Bu bağlamda yaratıcılık ilk olarak felsefenin, onu takiben psikoloji, sosyal bilimler, güzel sanatlar, eğitim vb. farklı disiplinler üzerinde teoriler üretmiştir (Onur ve Zorlu, 2018). Yaratıcılık ve yaratıcı düşünme, tarihin her dönemimde toplumların ilgi ve dikkatini çekmiş ancak toplumlar yaratıc düşünmeyi uzun yıllar yalnız, doğuştan üstün yetenekli ve dâhi insanlara özgü entelektüel bir süreç veya ürün olarak görmüşlerdir. Yirminci yüzyılın ikinci yarasından sonra yaratıcı düşünme üzerinde yoğunlaşan araştırmalar bu tabunun yıkılmasını sağlayarak her insanın az veya çok yaratıcılık becerilerine sahip olduğunu ortaya koymuştur (Ar1oğlu, 1999). Uzun yıllar boyunca sanatın ve edebiyatın bağlamında değerlendirilen yaratıcılık (Kanlı, 2017), yine uzun bir süre bilim ve teknikte buluş yapan bilim adamları veya mucitlere özgü bir ayrıcalık veya onların sahip olduğu bir nitelik olarak düşünülmüştür. Yaratıclık ve yaratıcı düşünme, önceleri mimarlık, reklamcılık, sanat gibi alanlarda kendini göstermiş olsa bile yirminci ve yirmi birinci yüzyılda eğitimden ekonomiye, sağlıktan teknolojiye kadar birçok alanın gelişmesinde anahtar kavram olarak karşımıza çıkmaktadır (Koray, 2005). Özellikle II. Dünya Savaşı'nı takiben askeri savunma sistemleri, mühendislik ve uzaycılık gibi alanlarda hızlı ilerleme kaydedilmeye başlanmıştır. Bu durumun bir sonucu olarak, son yıllarda gelişmiş ülkeler başta olmak üzere gelişmekte olan ülkeler de yaratıcılık, yaratıcı düşünme konusu ve eğitimi üzerine çalışmalarını yoğunlaştırmış ve yaratıcılığ 1 ve yaratıcı düşünmeyi eğitimin temel amacı olarak ele almaya başlamışlardır (Rawat, Qazi \& Hamid, 2012; Shaheen, 2010). 
Eğitimin temel amaçlarının belirlenmesinde önemli bir işleve sahip olan ve Bloom'un editörlüğünde yayımlanan eserde, bilişsel alanın taksonomisi yapılmış ve bu taksonomide eğitimin amaçları bilgi, kavrama, uygulama, analiz, sentez ve değerlendirme biçiminde kategorileştirilmiştir (Bloom ve diğ., 1956). Ancak aradan geçen zaman diliminde yaratıcılık konusunda yapılan çalışmalar, yaratıcılığın ve yaratıcı düşünmenin önemini bilimsel yönden daha net ortaya çıkarmıştır. Birgin'e (2016) göre sentez basamağının değerlendirme basamağından daha karmaşık zihinsel süreçleri içerdiği yönündeki eleştiriler veya görüşler dikkate alınmış, sentez basamağının yeri değerlendirme basamağı ile değiştirilmiş ve aralarında yaratıcı düşünmenin de yer aldığı "üst-düzey düşünme" süreçlerini vurgulaması bakımından "üretmekyaratmak" olarak yeniden adlandırılmıştır. Dolaysıyla orijinal taksonomi olan bilgi, kavrama, uygulama, analiz, sentez ve değerlendirme basamakları revize edilmiş taksonomide hatırlama, anlama, uygulama, analiz etme, değerlendirme, üretme (yaratma) şeklinde karşımıza çıkmaktadır. Önemi ve işlevinden dolayı eğitimin amaçlar hiyerarşisinde en üst sırada yer alan yaratıcılık, bugün aynı zamanda içlerinde ülkemizin de yer aldığı birçok ülkenin eğitim sistemlerinin temel amaçlarından birisi hâline gelmiştir.

İlköğretimden üniversiteye kadar bütün örgün eğitim kademelerinde yer alan öğretim programlarında (derslerde) bireylerin yaratıcılıkları ve yaratıcı düşünme becerilerinin geliştirilmesi hedeflenmektedir. Yaratıclık ve yaratıcı düşünme üzerine yapılan çalışmalar bu becerilerin her insanda var olduğuna ve eğitimle geliştirilebileceğine işaret etmektedir. Dolayısıyla, yukarıda da vurgulandığı üzere eğitimle geliştirilebilmesi mümkün olan yaratıcılık ve yaratıcı düşünme becerisi, aynı zamanda eğitim sistemlerinin önemli bir çıtısı olarak değerlendirilmektedir. Bu noktada eğitim kurumlarından yaratıcı düşünen bireyler yetiştirmeleri, bireylerin bu özelliklerini geliştirmeleri, hiç olmazsa bireylerin bu konudaki mevcut potansiyellerini köreltmemeleri beklenmektedir.

\section{Çalışmanın Önemi}

Alanyazında yaratıcılık ve yaratıcı düşünmeyle ilgili yapılan çalışmalara bakıldığında öğretmenler üzerinde ve okul öncesinden üniversiteye kadar bütün öğrenim kademelerinde yürütülen çalı̧malara rastlanmaktadır (Akar Gençer, 2014; Çeliköz, 2017; Eker ve Sak 2016; Erten Tatlı, 2017; Gizir Ergen 
ve Köksal Akyol, 2012; Kanll, 2017; Kara ve Şençiçek, 2015; Karabey ve Yürümezoğlu, 2015; Karlıdağ, 2018; Onur ve Zorlu, 2018; Şahin ve Danışman, 2017; Toyran, 2015; Ülger, 2012). Araştırmaların büyük çoğunluğu yaratıcıllk; yaratıcllğın ve yaratıcı düşünmenin ne olduğu; yaratıc düşünmenin eğitimde nasıl yer alabileceği; yaratıcılı̆̆ın farklı değişkenlere göre incelenmesi; yaratıcı düşünmeye dayalı etkinliklerin faklı değişkenler üzerine etkileri; ölçek uyarlama; yaratıcılığı ölçmede kullanılan araçlar; yaratıcılığı geliştirmeye yönelik teknikler ve zihinsel süreçler; yaratıcllğa ilişkin görüş, düşünce, inanç ve farkındalıklar; yaratıcılık ile öğretmen davranışları, akademik başarı vb. çeşitli değişkenlerle ilişkisi konularında çalışmalar olduğu görülmektedir. Bu çalışmada yaratıcılık ve yaratıcı düşünmeyle ilgili verilen içeriğe, konuyla ilgili kaynakların çoğunda bir bütün olarak yer verilmediği görülmektedir. Yaratıcllık ve yaratıcı düşünmenin kuramsal temelleri bağlamında tüm boyut ve paydaşlarıyla kapsayı ı bir şekilde ele alan bu çalışmanın alanyazına katkı sağlayacağı ve konuyla ilgili genel bir kılavuz kitapçık görevini gerçekleştireceği umulmaktadır.

\section{Çalışmanın Amacı}

Bu çalışma, yaratıcılık ve yaratıcı düşünmeyle ilgili alanyazında yer alan ve ulaşılan kaynaklardaki bilgileri derleyerek bir çalışma içerisinde sunmak amaciyla yapılmıştır.

\section{Yöntem}

Nitel araştırma yaklaşımı çerçevesinde yapılan bu çalışma "derleme" niteliği taşımaktadır. Yapılan çalışma eğer araştırma problemine değil de konu başlıklarına odaklanıyor ve önceliği konu başlıklarını ele almaya veriyorsa bu durumda yapılan çalışma bir derleme çalışması olarak değerlendirilebilir (Aydoğdu, Karamustafaoğlu ve Bülbül, 2017). Derleme çalışması, var olan çalışmaların fikir ve yaklaşımlarının özetlenmesine veya bunlardan bir sentez oluşturulmasına katkı sunmaktadır (Herdman, 2006). Dolayısıyla bu çalışmada, yaratıcılık ve yaratıcı düşünmeyle ilgili farklı kaynaklarda yer alan bilgi, fikir ve yaklaşımlar uygun konu başlıkları şeklinde derlenerek anlamlı bir bütün hâline getirilmiştir. 


\section{Yaratıcilık}

Yaratıclık, bugünkü bilimsel gelişmelere rağmen tanımlanması ve ortak bir anlayışla ele alınması zor olan kavramlardan birisidir. Çok boyutlu bir fenomen olan yaratıcılık kavramı, araştırmacılar tarafından disiplinlere, ekollere, yaklaşımlara ve ilgili disiplinin özelliklerine göre farklı açılardan ele alınmakta ve alanyazında farklı şekillerde tanımlanmaktadır (Onur ve Zorlu, 2017a; 2018). Latince "creare" kelimesinden gelen yaratıcıllk kavramının Batı dillerindeki karşıllı̆ı "kreativitaet, creativity" olarak geçmektedir. Bu kelime, "yaratmak, doğurmak, meydana getirmek" anlamlarında kullanılmaktadır (San, 2004). Sözlük anlamılla yaratıcılık, "yaratıcı olma durumu; her bireyde var olduğu kabul edilen, bir şeyi yaratmaya iten farazi yatkınlık" olarak tanımlanmaktadır (TDK, 2019a). Anlam olarak birbirine yakın olsa da yaratıcllık kavramın alanyazında çok sayıda tanımı yer almakta, farklı disiplin, ekol ve yaklaşımların geneli dikkate alınarak yaratıcılığın farklı tanımlarına aşağıda yer verilmektedir.

Yaratıcılık, bozukluklara, sorunlara, bilgi eksiğine, kayıp ögelere, uyumsuzluğa karşı duyarlı olma, çözüm arama, güçlügü tanımlama, kestirmelerde bulunma; eksikliklere ilişkin hipotezler geliştirme, bu hipotezleri sınama, değiştirme, yeniden sınama, daha sonra da sonucu ortaya koyma olarak tanımlanabilir (Özden, 2005). Yaratıcılık, kalıpları yıkma, alışılmışların dışına çıkma, diğerlerinin yaşantılarına açık olma, empoze edilmiş düşünce çizgisini kırma, bilinmeyenlere doğru bir adım atma ve yeni bir düşünce çizgisi ortaya koyma, bir problem için alternatif çözümler üretme, başka şeylere yol açan yeni bir şey bulma, başkalarının izlediği yoldan çıkma, yeni bir düşünce ortaya koyma, yeni bir ilişki kurma, bilinmeyen yeni bir teknik veya yöntem icat etme, insanlara faydalı olan bir araç veya bir aygit yapmadır (Rıza, 2000). Başka bir tanıma göre yaratıcılık eksikliklere, eksik öğelere, problemlere, bilgideki boşluklara, uyumsuzluklara (düzensizliklere) vb. karşı duyarlı olma, zorluğu tanımlama, çözüm arama, tahminde bulunma ya da bu eksiklikler hakkında hipotezler üretme, bu hipotezleri test etme, yeniden test etme ve bu hipotezleri değiştirerek sonuca varma sürecidir (Torrance, 1974; Akt: Gün-

gör, 2007). Konuyla ilgili olarak Craft (2003) yaratıcılığı; hayat boyu devam eden bir yetenek olarak açıklamış ve kendini ifade etme, zekâ ve hayal gücünü kullanma kapasitesi olarak tanımlamıştır. Yaratıcılık; sadece orijinal ve 
yeni bir ürün ortaya koymak değil mevcut bilgilerden yeni sentez yapma, sorunlara alternatif çözüm yolları bulma, yeni durumlara uyum sağlama ve nesnelerin işlevini alışılagelmişin dışında düşünmektir (Karataş ve Özcan, 2010). Yaratıcılık, yalın hâliyle ve sadece yoktan var etmek demek değildir. Çünkü yeni bir fikir çoğu zaman ya bilinen fikirlerin bir bileşimidir ya da eski bir fikrin yeni bir şekille formüle edilmiş hâlidir. Bu bağlamda yaratıcılık, eski fikirlere yeni kimlikler kazandırma ve bilinenlerden yeni sentezler oluşturma faaliyetleri olarak da tanımlanabilir (Bessis ve Jaqui, 1973).

Tanımlardan da görüleceği üzere yaratıcllık, her alanda düşünsel ve duyuşsal beceriler olarak algılanmasına rağmen kesin bir tanımını yapmak zordur. İlgili tanımlar daha çok yaratıcilığın karmaşık bir düşünme biçimi olduğu yönündedir (Özerbaş, 2011). Yine yaratıcılığın tanımından çok üzerinde uzlaşılan ortak nokta onun "yeni fikir, farklı bakış ya da orijinal ürün" olduğu, ortaya çıkan sonuca göre yaratıcılığın değerlendirilebileceğidir (Çeliköz, 2017). Kısaca yaratıclıkla ilgili tanımlar incelendiğinde yeni, yenilik, özgünlük, buluş kavramlarına vurgu yapıldığı görülmektedir (Gizir Ergen ve Köksal Akyol, 2012).

Yaratıcılık, yenilik ve değişim birbirine karıştırtılması mümkün olan üç kavramdır. Özellikle yaratıcılık ile yeniliğin eş anlamı olduğu düşünülebilir. Yaratıclık her alanda yararlı yeni fikir ve bilgilerin üretilmesi, yenilik ise bu yaratıc fikirlerin başarıyla uygulamaya konulması olarak tanımlanabilir. Dolayısıyla yeniliğin başlangıç noktası durumunda olan yaratıclık, yeniliklerin ve yeniliğin psikolojik algılanışlarının bir tohumu ve yeniliğin başlangıç noktası olarak görülmektedir. Yaratıcılık, yenilik için şarttır ancak tek başına yeterli değildir (Amabile vd., 1996; Akt: Duran ve Saraçoğlu, 2009). Yaratıcllık, yenilik meydana getiren zihinsel bir faaliyettir, yenilik ise yaratıcılığın dışsal ve somut bir sonucudur. Yaratıcılık, herhangi bir konuda veya düzeyde var olan durumu geliştirmek ve yenilik getirmek amacıyla kullanılır. Dolayısıyla yenilik kavramı gelişim ve değişim ile ilgilidir. Değişim yeni bir şeylerin oluştuğunu veya ortaya çıktığını, gelişim bu yeniliklerin olduğunu anlatmaktadır (Yıldırım, 2007). 


\section{Yaratıcılık Yaklaşımları}

Yaratıcılık kavramının alanyazında yerini almasını sağlayan ve tanımlara kaynaklık eden yaklaşımlar beş grupta ele alınabilir (Treffinger, 1996; Akt: Aslan, 2001a):

Akılcı yaklaşım: Bu yaklaşımı savunan araştırmacılar, yaratıcıllğın zihinsel ve bilişsel bir etkinlik olduğunu ileri sürmektedir. Yaratıcıllğı gizemli bir olgu olarak ele almaz, bireyin zihnini özgün ve verimli bir biçimde kullanma yolu olarak benimserler. Akılcı yaklaşıma göre yaratıclık; muhakeme etme, düşünme, birleştirme veya problem çözme çeşidi olarak görülmektedir.

Kişilik ve bireysel özellikler: Berkley Kişilik Değerlendirme ve Araştırma Enstitüsü'nün (IPAR) yaptığı araştırmada bilim adamı, sanatçı, yazar vb. kişilerden meydana gelen örneklemden üst düzeyde yaratıcı olan ve olmayan çiftlerin karşılaştırılması, psikanalitik çözümlemelere ve klasik kişilik teorilerine dayanan kuramların oluşturduğu verilerle yaratıcı bireylerin belirleyici kişilik özellikleri tanımlanmıştır. Elde edilen bulgulardan yola çıkarak yaratıcılığı bireysel özellikler açısından tanımlamaktadır.

Sosyal, kişiler arası faktörler: Rol tanımları, değerler ve beklentiler, ödül, normlar ve tasdik kurumlarına dayanarak desteklenecek yaratıcı dışavurumların tanımlanmasını içermektedir. Antropolojik, çevresel ve sosyolojik açıdan yaratıclığı geliştiren veya körelten çevresel faktörleri tanımlamaktadır.

Yaşam şekli: Yaratıı bireylerin yaşam biçimlerinden hareketle yaratıcılığ günlük hayata adapte etme görüşünü benimseyen yaklaşımdır. Kendini gerçekleştirme, kişisel tamamlama, kişisel büyüme ya da pozitif benlik imajı olarak yaratıcılığ tanımlamaktadır.

Mantıkî olmayan yön: Biyokimya, nöropsikoloji ve diğer bilimlerdeki araştırmalar, fiziki, biyolojik ve psikolojik faktörlerin etkileşimlerini incelemektedir. Yaratıcılığı; girdileri farklı şekilde işleme, dünyayı farklı algılama ya da orijinal bir sistem olarak fonksiyonda bulunma şeklinde görmektedir. 


\section{Yaratıcı Bireyin Özellikleri}

Yaratıcı bir birey merak, buluş yapma yetisi, sabır, serüvenci düşünme, imgelemci (hayal kurucu) olma ve imgelerle düşünebilme, deney ve araştırmalardan kaçmayan ve sentezci yargılara varabilen özelliklerini en başta taş1maktadır. Yaratıcılık ve yaratıcı düşünmeyle ilgili tanımlar, disiplinlere, yaklaşımlara ve ekollere göre farklılık gösterse de yaratıc bireyin özellikleri hakkında ortak kavramlar bulunmaktadır. Yaratıı bireyin genel özellikleri aşağıda yer almaktadır (Saban, 2004; San, 1985; Akt: Ercivan Zencirci, 2008; Starko, 1995; Artut, 2001; Getzels ve Csikszentmihalyi, 1976; Linderman, 1997; Akt: Öztürk, 2004):

- Gururlu ve alçak gönüllüdür.

- Sessiz ve rahattır, yüksek bir enerjiye sahiptir.

- Fanteziler, hayal kurma ve gerçekler arasındadır.

- Disiplini, eğlenceyi, sorumluluğu bir arada bulundurur.

- Çelişkili anlayışlara ya da yorumlara karşı kendisini korur.

- Zeki, acemi ve deneyimsizdir ancak yeni deneyimlere açıktır.

- Maceracı, meraklı, şakacı, neşeli, canlı, sezgili bir yapıya sahiptir.

- Olaylara karşı duyarlı, meraklı ve ilgilidir, gözlem gücü yüksektir.

- Doğruları eleştirir, bilgi boşluklarını yakalar, paylaşmaya isteklidir.

- Cesurdur, risk alır, kendisine güveni yüksektir, doğal ve güvenilirdir.

- Enerjiktir isteklidir, idealisttir, azimlidir, deneme yapmaya heveslidir.

- Bağımsızdır ve yalnız kalmayı sever, gerekirse uzun zaman çalışabilir.

- Duyarlı ve açık görüşlü olması ona acı verse dahi bu yönünü açı̆ga vurur.

- İşinde hırslı ve ateşlidir, öznel düşünebilir, kolay çözümlerden hoşlanmaz.

- Zaman zaman yalnız vakit geçirmeye ihtiyaç duyabilir, derin düşünebilir, değişen gerçeklere çözüm bulabilir.

- Sıradan kişinin kesin ve katı boyutunu taşırken, diğer yandan da özgün ve biricik bir kişinin eğilimlerini sergiler.

- Akıcılık (belirlenen süre içerisinde çeşitli önerilerde bulunmak), esneklik (nesnelerle ilgili farklı kullanım önerme) ve elaborasyon (sözel veya görsel detaylandırabilme, detayları fark etme ve görme) özelliklerini taşır.

- Olumlu benlik algısı, başarı, mantıklı düşünme, kuşku, tahmin, idealist, özgüven, şaka, mizah, esnek, özgün, yarg1 ve fikirlerde özgür, yeni fikirlere açık, eleştiriye açıklık ve eleştirel olma, ifade ve düşüncede akıclık, 
huzlı düşünme ve hareket etme, çabuk kavrama, yenilik, özgünlük, birleştirme temel göstergeleridir.

\section{Yaratıcılıkla İlgili Yanlış Anlaşılmalar}

Yaratıcılık günümüzde önemli olduğu kadar aynı zamanda yanlış anlamalara da neden olan bir kavramdır. Yaratııılıkla ilgili yanlış anlaşılmalar şu şekilde özetlenebilir (Fisher, 1995; Ruggiero, 1988; Akt: Doğanay, 2012):

Yaratıcılık sadece belli alanlarda olur: Yaratıclığın genellikle müzik, edebiyat, sanat gibi alanlarda olduğu konusunda yaygın bir kanı bulunaktadır. Sadece bu alanlara özgü bir kavram olmayan yaratıclık her yerde, yaşamın her alanında ve diğer bilim dallarında da olabilir.

Yaratıcılık yüksek düzeyde yetenek ve zekâ gerektirir: Yaratıcllğın üst düzeyde bir zekâ ve farklı alanlarda yetenek gerektirdiği yaratıcılıkla ilgili başka bir yanlış anlaşılmadır. Yaratıcılıkla ilgili yapılan araştırmalar yüksek düzeyde zekâya sahip olan bireylerin her zaman yaratıcı olmadıklarına işaret etmektedir.

Yaratıcı insanlar hiç çabalamadan yaratıcı ürünler ortaya çıkarabilir: Yaratıcılı̆̆ın bir esin sonucunda birden bire ortaya çiktığı, yaratıcılık için yoğun bir çabaya ihtiyaç olmadığı düşüncesi de yaratıcılıkla ilgili diğer bir yanlış anlamadır. Kaldı ki bunun tersi, yaratıcı bir ürün ortaya koymak için yoğun ve sürekli bir çabaya ihtiyaç duyulmaktadır. Bilim ve uygarlık tarihi bunu örneklendirmeye yeterlidir. Edison, elektrik lambasını yorucu ve uzun denemeler sonunda icat etmiştir.

Uyuşturucu kullanımı yaratıcılı̆̆ı artırır: Uyuşturucu veya bu özellikteki başka maddelerin kullanımı zihni esnettiği ve yaratıcılığın bu özgür ortamda daha iyi ve fazla geliştiği kanısı da yanlış anlamalardan bir diğerini oluşturmaktadır. Yaratıcılığın esnek ve özgür bir zihinde geliştiği doğrudur. Ancak aynı zaman da zihnin sistemli ve kontrollü çalışması gerekir ki uyuşturucu bu durumu engelleyici bir faktördür. 
Yaratıcı kişiler zihinsel olarak dengesiz olur: Bazı insanlar, yaratıcı ve toplumda "deli" diye adlandırılan insanların birbirine çok benzediğine inanırlar. Ancak yapılan çalışmalar bu görüşün tersine, yaratıcilı̆ın daha sağlıklı bir zihne sahip olunması gerektirdiği konusunda sonuçlar tespit edilmiştir. Bunun olası nedeni; yaratıc bireylerin toplumun genel norm ve beklentilerinden farklı davranışlar gösteren insanlar olduğu ve kendilerine bu farklılıklarından dolayı "deli" yakıştırmasının yapıldığı olabilir.

\section{Yaratıcılı̆̆ın Boyutlar}

Çalışma konusu ve alanı bakımından yaratıclıkla ilgilenen çeşitli araştırmacllar yaratıcılığın dört ana boyuttan oluştuğunu ileri sürmüşlerdir. Yaratıcllğın temel boyutları ve boyutların genel özellikleri şu şekilde açıklanabilir (Duman, 2011; Fisher,1995; Akt. Doğanay, 2012; Rawlinson, 1995; Akt: Ersoy ve Başer, 2009; Torrance, 1962; Akt: Dere, 2017):

Akıcılık: Bellekte saklanılan bilgilerin ihtiyaç anında akıcı ve hızlı bir şekilde kullanılmasıdır. Akıcılık aynı zamanda hemen çözüm bulma ve çok fikir üretmedir. Örneğin meteoroloji sözcüğünden jilet, et, tere, mit, mor, eter vb. gibi sözcükler üretmek olasıdır.

Esneklik: Karşılaşılan bir sorunu çözerken, zihinde var olan kalıpları yıkarak özgür düşünmeyi vurgulamaktadır. Yaratıcı davranışların farklı yollarla sergilenmesi, görev içindeki değişiklik, bir görevi yerine getirirken strateji değişikliğine giderek düşünceyi bir yönden başka bir yöne değiştirmektir. Zihinsel esnekliğin eksikliği veya yokluğu eleştirel düşünme yönünden bireyler için olumsuz bir faktördür. Zihinsel katılık, sadece eleştirel düşünme gücünün değil birçok kişilik özelliklerinin de yokluğuna sebep olabilir.

Özgünlük (orijinallik): Karşılaşılan bir soruna farklı veya alışılmadık çözümler üretebilmektir. Bir olay ya da konuyla ile ilgili farklı ve özgül tepkiler ortaya koyabilmedir. "Atık kâğıtlar hangi amaçlarla kullanılabilir?" soruna yönelik ulaşılan çözüm bir başkasının çözümü ile aynıysa orada orijinallikten bahsetmek doğru değildir. Örneğin, "dizüstü bir bilgisayarı daha işlevsel hâle getirebilmek için ona neler eklenebilir?" 
Ayrntılama (detaylara girme-zenginleştirme): Zenginleştirme, düşünmeyi uzatmayı, fikirleri toplamayı ve detayları vermeyi gerektirir. Dışarıya yansıyan düşüncelerin veya fikirlerin sonuçlarında bütün detaylara yer verilmesi, bu detayların da en iyi fikirleri içermesidir. Bir olayın, nesnenin, bilginin en ince detaylarına varıncaya kadar analizlerini yapmak ve inceden inceye değerlendirmektir. Ayrıntılama bir şeyin benzerini ve farklılı̆̆ını belirleyip s1nıflamasını ve sıralamasını yaparak ona bir estetik ve konum kazandırmadır.

\section{Yaratıcılı̆̆ın Aşamaları}

Yaratıcı düşünmenin aşamalarının oluşumu hep aynı sırada gözlemlenmeyebilir, bazen bir paralellik söz konusu iken bazen de aşamalar arasında sıçramalar yaşanabilir. Yaratıı düşünmenin aşamaları ve bu aşamaların genel özellikleri aşağıda yer almaktadır (Aslan, 2001b; Doğan, 2007; Duffy, 1998; Yıldırım, 1998; Bentley; 1999; Akt: Ercivan Zencirci, 2008; Erlendsson, 1999; Akt: Taşpınar, 2012; Rawlinson, 1995; Akt: Ersoy ve Başer, 2009; Yavuzer, 1994):

Hazırlık aşaması (keşif): Problemlere yönelik bilinçli, sistematik ve mantıklı yaklaşma işlemlerini kapsayan aşamadır. Gereksinim veya gerçekleştirilmek istenen durum belirlenir, tanımlanır. Bu durumla ilgili bilgi veya malzeme toplanır. Bireyler olayları, nesneleri, düşünceleri aktif olarak gözetler, problemin çözümüne yönelik bilgi ve malzemeyi toplar. Bunu sağlamak için bireyin okuması, deneyimli kişilerle tartışması, tartışma ortamında yer alması, farklı alanlarda çalışma yapması gerekir.

Kuluçka aşaması (oyun): Bu aşamada başka sonuçlar ve işler üzerinde düşünen bireylerin zihinleri aynı zamanda sorun için çalışmasını sürdürmektedir. Hazırlık aşamasından sonra bireylerin kendini rahatlamaya bıraktığı bu aşama bireyler açısından biraz durgun geçmektedir. Problemlerin çözümü zaman zaman bilinçaltında gerçekleşebilir. Bu durum bireylerin ilgisi olmayan bir sorunla bağlantılı bir etkinlik yapmaları durumunda daha sıklıkla ortaya çıkabilir, hatta uykuda bile gerçekleşebilir. Problemlerin çözümüne ilişkin orijinal ve yeni görüşler ortaya çıtığı bu aşama süre olarak çok uzun veya çok kısa zaman alabilir. Bu aşamada derin düşünme, dalgin düşünme, bilinçaltı süreçler, duyumsama, görselleştirme gibi yetiler iş başındadır. 
İçe doğuş aşaması (yaratıcılık-aydınlanma): Karşılaşılan sorunun çözümüne yönelik düşüncenin, çözümün ya da yapılacak şeyin ani bir şekilde ortaya çıtığı aşamadır. Birey, problem veya materyalle ilgili olağanüstü keşif yapar veya yeni yaklaşımlarda bulunur. Problemlere yönelik alternatif çözümlerin zihinde belirginleştiği, canlandırıldığı ve çözüm bulunduğu bu aşama anlıktır. Yaratıcı düşünmenin oldukça heyecan verici olan bu aşamasını, yaratıcı bireyler başarıyla tamamlarlar. Bu aşamada fikirler çarpııı bir anda, yavaş ama emin bir şekilde ortaya çıabilir.

Değerlendirme aşaması (sonuçları doğrulama-çözüm getirme): Bir önceki aşamada ortaya konan fikirlerin, çözüm önerilerinin ve yaklaşımların analiz edildiği, denendiği, bunların geçerli ve yeterli olup olmadığının ortaya konulduğu ve gerekli son düzeltmelerin yapıldığı aşamadır. Mantıklı ve bilinçli düşünmenin ağırlıklı olduğu bu aşamada problemlere ilişkin çözümler sınanır, varsa aksaklıklar ve eksikler giderilir. Yaratıcı bir uğraşın en zor aşamasını oluşturan bu süreç diğer aşamalara göre daha fazla cesaret, özgüven ve kararlılık gerektirir. Yaratıcı bireyler geçici veya aşılabilecek engellerle karşılaştıkları zaman yaratıcı fikrini uygulamaktan vazgeçmezler.

\section{Yaratıcılıkla Anlamlı İlişkisi Olan Faktörler}

Alanyazında yer alan kuramsal bilgiler ve konuyla ilgili yapılan araştırmalar zekâ, beyin, ıraksak düşünme ve hayal gücünün yaratıcılığı etkilediği veya yaratıcılığın bu öğelerle anlamlı ilişkisi olduğunu göstermektedir. Bunların dışında yaratıcılık ile yaş ve cinsiyet arasında bir ilişki bulunmaktadır. Ancak bu ilişkinin çoğu kaynakta anlamlı derecesinde olmadığı belirtilmektedir.

Yaratıcılık ve zekâ: Alanyazın incelendiğinde yaratıcılıkla en fazla ilişkisi araştırılan değişkenin zekâ olduğu görülmektedir. Bilimsellikten uzak olsa da toplumlar genellikle yaratıcılığı zekâ ile açıklamaya çalışmış, kimi zaman ve durumlarda da her iki kavramı özdeşleştirmişlerdir. İnsanın en yaratıcı olduğu dönem çocukluk dönemi olarak kabul edilse bile genel olarak her yaşta zekâ, yaratıcılığa önemli katkı sağlamaktadır (Starko, 2001; Ruggiero, 2004; Akt: İnal Kızıltepe, Can Yaşar \& Uyanık, 2017). Yaratıcılık ve zekâ ağırlıklı olarak bireylerin doğuştan getirdiği yeteneklerdir. Her iki yetenek de uygun çevre koşulları ve eğitimle keşfedilebilir ve geliştirilebilir (Tekin, 2008). 
Konuyla ilgili olarak Getzels ve Jackson (1962) zekâ ile yaratıcilı̆ı̆n doğru orantılı olduğunu dile getirmekte ve zekâ düzeyi yükseldikçe bireylerin yaratıı etkinliklerde daha başarılı olduklarını vurgulamaktadır (Can Yaşar, 2009).

"Zekâ ile yaratıcılık arasındaki ilişki düzeyi" üzerinde oldukça çalışılan bir konudur. Konuyla ilgili yapılan birçok araştırma sonucuna göre zekâ ile yaratıclık arasında yüksek düzeyde anlamlı bir ilişki ortaya çıkmış olmakla beraber bu ilişkinin mutlak olmadığı da vurgulanmaktadır. Yaratıcılık için bireylerin belirli bir zekâ düzeyinde olmaları gerekmekle birlikte yaratıcılığa sahip bireylerin zekâ seviyelerinin de yüksek düzeyde olduğunu söylemek zordur (Özerbaş, 2011). Bu iki değişken arasında az ilişki olduğunu ya da ilişki olmadığını belirten araştırmacılar olduğu gibi, araştırmaların çoğu yaratıclık ve zekâ arasındaki ilişkinin belirli bir zekâ seviyesine kadar geçerli olduğunu, belli bir zekâ düzeyinden sonra ise bu ilişkinin kaybolduğunu ortaya koymaktadır. Bu duruma aynı zamanda "eşik kuramı" denilmektedir (Erten Tatll, 2017). Konuyla ilgili olarak Cronbach (1970), eşik kuramındaki zekâ düzeyinin 120 IQ olduğunu belirtmekte, zekânın yaratıcılık için gerekli ancak tek başına yeterli olmadığını vurgulamaktadır. Yaratıcılığın önemli ön koşul olan faktörlerinden birisi olan zekâ tek başına yaratıcılığın ön şartı değildir. Konuyla ilgili yapılan araştırmaların genel olarak ortak sonucu, yaratıcılık ile zekâ arasında orta düzeyde ve anlamlı bir ilişki olduğunu vurgulamaktadır.

Kogan ve Wallach, ilkokul öğrencilerine yönelik geliştirdikleri yaratıclık testini serbest, standart zekâ testlerini de kontrollü koşullarda uyguladıktan sonra, çocukları yaratıcılık ve zekâ puanlarına göre dört gruba ayırmış ve her gruptaki öğrencilerin kişilik özelliklerini şöyle belirlemişlerdir (Topaktaş, 2001):

$\checkmark \quad$ Yaratıcılık ve zekâ düzeyi yüksek olan öğrenciler: Bu grupta yer alan öğrencilerin başarılı, uyumlu, amaçlı ve arkadaşları tarafından değerli bulunan, hem erişkin hem de çocukça davranan bireyler olduğu gözlenmiştir.

$\checkmark \quad$ Yaratıcılık ve zekâ düzeyi düşük olan öğrenciler: Burada yer alan öğrencilerin kendilerine az güvendikleri, arkadaşlarınca kabul edilmeyen öğrenciler olduğu gözlenmiştir. Bu öğrencilerin kendilerini zaman zaman 
atletizme verdiklerini ve kavgaya karıştıklarını, bazen de aşırı motor hareketlere yöneldiklerini ve kendilerinden daha başarılı öğrencileri taklit ettikleri gözlenmiştir.

$\checkmark \quad$ Yaratıcılık düzeyi düşük ve zekâ düzeyi yüksek olan öğrenciler: Bu gruptaki çocukların bazen sakin ve içe kapalı olma eğiliminde, bazen yaş grupları ile ilişki kurmada güçlükleri olduğu gözlenmiştir. Ayrıca bu gruptaki çocukların okul başarısına çok önem verdikleri, başarısızlığı bir felaket olarak nitelendirdikleri ve felaket ihtimaline karşı devamlı olarak çalışma çabası içerisinde oldukları da belirlenmiştir.

$\checkmark \quad$ Yaratıcılık düzeyi yüksek ve zekâ düzeyi düşük olan öğrenciler: Bu gruptaki çocukların güven duygusundan yoksun, endişeli ama tedbirli olma eğiliminde oldukları gözlenmiştir. Yaşıtlarından uzak oldukları ve arkadaş aramadıkları izlenmiştir. Akademik başarı kritik olduğu hâlde, sık sık bozgunluk yaptıkları, ne kendileri ile ne de okulda huzurlu olmadıkları ama rahat bir atmosferde mutlu ve yaratıcı oldukları gözlenmiştir.

Yaratıcılık ve yaş: Yaratıcllık ile ilgili olan diğer kavram ise yaştır. Okul öncesi dönem, çocuğun duygusal, fiziksel, zihinsel, sanatsal, sosyal vb. birçok gelişim alanlarının en çok hız kazandığı dönemdir. Ülkemiz açısından yaratıcılık eğitiminde temel sorunun erken çocukluk dönemi olarak kabul edilen 2-5 yaş arasında yaratıcılık \%90 oranında bir gelişme gösterirken 6-7 yaşlarından itibaren bu oran \%20 düzeyine kadar düşebilmektedir (Kara \& Şençiçek, 2015). Ülkemizdeki oranla benzer olmasa da dünya genelinde de yaş ilerledikçe yaratıcılık düzeyinde düşüş yaşanmaktadır. Bogoyavlenskaya (2013), boylamsal bir çalışma yaparak anasınıfına ve ilkokula devam eden öğrencilerin yaratıcılık skorlarındaki değişimleri incelemiş ve çalışmasında altı yaşındaki çocukların ilkokula başlamasıyla birlikte yaratııılık skorlarında bir düşüşün yaşandığı görülmüştür. Benzer şekilde Torrance; çocukların yaratıcllıklarının okula başladığında akademik beklentiler ve otorite yüzünden ya olduğu gibi kaldığını ya da düşmeye başladığını belirtmektedir (Akar Gençer, 2014). Bu düşüşün temelinde çevresel faktörler bulunmaktadır. Çünkü okula başlayan ve yeni bir ortamın içerisine giren çocuklar kuralları ve otoriteyi tanımaktadır. Bu nedenlerden dolayı yaratıcılıkta bir duraklama, eğer ortam olumsuz şartları barındırıyorsa da gerileme olmaktadır (Toyran, 2015). 
Yaş ilerledikçe tecrübelerin artması, sosyalleşme, öğrenim hayatı, toplumun yazılı ve yazısız kuralları yaratıcılığı olumlu ya da olumsuz olarak etkilemektedir. Gelişim alanlarında olduğu gibi yaratıcılık açısından da sağlam temellerin atılması veya atılmaması nedeniyle okul öncesi gelişim dönemi oldukça etkilidir. Hayatın ilk yıllarında kazanılan temel bilgi ve becerilerin kalıcı etkileri olduğu bir gerçektir. Ancak yaratıcılığın gelişim dönemi veya yaş açısından herhangi bir dönem ve yaş aralığına indirgemek de çok doğru değildir. Konuyla ilgili yapılan birçok araştırma yaş ile yaratıcılık arasında anlamlı bir ilişkinin olduğunu kesin kanıtlar nitelikte sonuç elde etmemiştir. İlk tohum atılması ve çekirdek açısından okul öncesi dönem oldukça önemlidir. Ancak bu dönemde atılan yaratıcılık tohumlarının filizlenmesi ve olgunlaşması açısından her yaş önemli görülmelidir. Bu noktada Argun (2012), her yaş döneminde yaratıcılığın gelişmesi için bir önceki yaş döneminin veya daha önceki yaş dönelerinin özelliklerinin iyi öğrenilmiş olması gerektiğine dikkat çekmektedir. Çünkü yaratıcılık dönemlerinin aşamalı bir düzen içerisinde geliştiği bilinen bir gerçektir. Yaratıcı özelliğe sahip olarak dünyaya gelen her birey yaratıcıdır ancak hangi yaşta olursa olsun bireylere sağlanan imkânlar, bireylerin sahip oldukları çevre ve tutumları yaratıcılıklarını olumlu veya olumsuz etkilemektedir.

Yaratıcılık ve beyin: Araştırmacılar beyni kafa (occipital), ön (frontal), yan kafa (pariental) ve şakak (temporal) lob olarak adlandırılan dört bölgeye ayırmaktadırlar. Kafanın ön bölgesinde yer alan ön lob problem çözme, planlama, karar verme ve yaratıcılık gibi maksatlı eylemleri kapsamaktadır (Jensen, 1998). Bilginin gerekli durumlarda yaratıc bir şekilde kullanılması için beynin birçok bölgesinin eşgüdüm hâlinde çalışmasını gerektirmektedir. Yaratıclık, beyindeki pek çok bölgenin ve lobların eş zamanlı ve eş güdümlü çalışması ve bir bileşimi sonucu ortaya çıkmaktadır. Yaratıcılık daha çok beynin ön alın lobu dediğimiz frontal loblarındaki nöron hücrelerinin daha belirgin bir elektro-kimyasal nöron demetlerinin (network) etkinlik meydana gelmesiyle oluştuğu vurgulanmaktadır. Bu noktada frontal loblar, kimyasallar yayarak beynin farklı bölgeleri arasında bağlantı kurulmasını da sağlamaktadır. Frontol lobların zekâ, kişilik, yaratıcılık, planlama, problem çözme gibi görev ve strateji değiştirme konularında etkin olduğu bilinmektedir. Ya- 
ratıclık testlerinde yüksek başarının, frontal lob aktivasyonuyla ilgili olduğuna ilişkin bulgu ve sonuçlara ulaşılmıştır (Carlsson, 2000; Jensen, 200; Sousa, 200; Akt: Duman, 2011).

Başka bir ayrıma göre de beyin sağ ve sol olarak iki yarıküreye ayrılmakta, beynin sağ ve sol yarısı farklı işlevleri yerine getirmektedir. Hafızası oldukça güçlü, enerji dolu, tipik bir kuramcı olan ve olayları tümdengelimle inceleyen sol beyin, aritmetik işlemler, okuma-yazma, ayrıntıların irdelenmesi vb. analitik işlevleri yerine getirmektedir. Soyut kavramlarla uğraşmayan, ayakları yere basan, duygularla yüklü olup uygulamalı olaylara yönelik olan ve olayları tümdengelimle inceleyen sağ beyin ise jestlerle kendini ifade eder, mimiklerle konuşur, şekil ve resimleri çok iyi ayırt eder ve yorumlar (Kale, 1994).

Yaratıcılık ve ıraksak düşünme: Genel anlamda bireyler yakınsak ve ıraksak olarak adlandırılan iki tip düşünme boyutuna sahiptirler. Yakınsak düşünme (convergent), çok bilinen yanıtlara dayalı, tek doğru cevap odaklı, doğrusal ve mantıksal düşünme boyutudur. Iraksak düşünme (divergent) yaratıcı düşünmenin temelini oluşturmakta, birden fazla ihtimalin varlığına dayanan, sıra dışı ve orijinal fikirler üreten düşünme boyutudur (Guilford, 1984; Akt: Tuğrul, 2006). Yaratıcllğ geliştirmede önemli bir faktör olan rraksak düşünme, denence hâline getirme, mümkün olan ve kanitlarla desteklenebilen belirli sayıdaki cevabı teşvik etme veya anlamlı soru sorma anlamını taşımaktadır. Yakınsak düşünme yanıtı önceden belli olan sorulara; ıraksak düşünme ise yanıtı önceden belli olmayan, özgün veya yaratıcı birden çok yanıt gerektiren sorulara odaklanır (Harris, 1998; Akt: Doğanay, 2012).

“Türkiye' nin en kalabalık şehri hangisidir?" sorusu yakınsak düşünmeyi; "İstanbul neden veya niçin Türkiye'nin en kalabalık şehri hâline gelmiştir?" veya "Türkiye'de nüfus göçünü önlemek için hangi tedbirler alınmalıdır?" soruları ise rraksak düşünmenin cevap bulması gereken sorulardır. Rutin dışı, açık uçlu sorulara cevap bulmaya yönelen, ölçülebilir ve değerlendirilebilir bilgiden çoklu cevaplar üreten, problemlere duyarlılık gösteren düşünme biçimi olan ıraksak düşünme bir bakıma yaratıcılığın bilişsel temelini oluşturmaktadır (Guilford, 1950; Gartenhaus, 2000; Akt; Ülger, 2012). Yaratıcllıkta ve yaratıcı düşünmede, öncelikle çok yönlü bakış açısının bu bağlamda rraksak düşünme şeklinin yerleşmesi gerekir. Bilgiyi kullanarak değişik ya- 
nıtlar üretilmesini sağlayan rraksak düşünme, çeşitli açılardan özgürce düşünmedir, özgündür, keşfedicidir, tek çözümlü değildir, ayrıntıya odaklanır, var olan fikirleri geliştirir (San, 1985; Akt: Ercivan Zencirci, 2008; Yenilmez ve Yolcu, 2007).

Konuyla ilgili yapılan bazı çalışmalarda bireylerin yaratıcı düşünme becerilerinin ölçülüp değerlendirilmesinde rraksak düşünmeyi ölçen veri toplama araçları kullanılmıştır. Bu çalışmalar ıraksak düşünme yetisi yüksek bireylerin yaratıcılık düzeylerinin de yüksek olduğunu göstermektedir. Bu durumda yaratıcılık ile ıraksak düşünme arasında anlamlı bir ilişki olduğu söylenebilir (Karabey ve Yürümezoğlu, 2015). Yaratıcı düşünme sürecini açklayan araştırmalarda genellikle rraksak düşünmenin önemini vurgulansa da yakınsak düşünmenin de bu süreçte önemli olduğu bilinmektedir. Brophy (2000), Dietrich (2004) ve Starko'ya (2010) göre yaratıcılık, yakınsak ve iraksak düşünme biçimlerinin ikisini de içermektedir. Yeni fikir, öneri, ürün vb. ortaya çıkması ıraksak düşünmeyle olsa dahi sürecin ilerleyen aşamalarında bu fikirlerin kullanışl, işlevsel, yararlı olmasında yakınsak düşünme de rol oynamakta, ıraksak ve yakınsak düşünme problemlerin çözümünde birbiri ardına süregelen bir bütün olarak karşımıza çıkmaktadır. Dolayısıyla bilişsel alanın üst basamaklarına doğru çıkıldıkça ıraksak düşünmenin de artacağı, ıraksak düşünmenin artmasının da yaratıcılığa ve yaratıcı düşünmeye daha fazla katkı sunacağı söylenebilir.

Yaratıcılık ve hayal gücü: Hayal etme, bilinen fikirlerle, objelerle ve materyallerle zihinsel bir olgu veya ortam tasarlamaktır. Özgün ve yeni ürünlerin ortaya çıkmasında aktif ve güçlü bir hayal gücü önemli bir işleve sahip olup hayal etme yaratıcılık açısından önemli rol oynamaktadır. Yaratıc bireylerin en önemli özellikleri arasında hayal güçlerinin kuvvetli olması da yer almaktadır (Leboutiller ve Marks, 2003). Hayal gücü, bireyin duygu, beden ve düşüncelerini bir noktada toplayarak bu unsurların birbirleriyle ilişkilendirmesi olarak tanımlanabilir (Tok, 2008). Yaratıcılığın tanımlarından biri hayal gücünü kullanabilmedir. Yaratıı birey; özgün, yeni ve değerli bir şeyler üretmek veya var olan bir şeyi başka bir şeye transfer etmek için hayal gücünü kullanan kişidir (Öztürk, 2004). Sanat, edebiyat, teknoloji, mimari, yemek kültürü, spor, moda, töreler, mistik inanışlar, örf ve adetler, hatta benlik algılar bile yeryüzünün fiziksel sınırlarının ötesinde olan ve sonsuza uzanan hayal gücü denizinin içerisinde oluşmaktadır (Orhon, 2014). Bu noktada Bolen ve 
Torrance (1978) araştırmasında özgür düşünmek, değişime açık olmak ve hayal gücünün yaratıcı kişilik özelliğinin üç temel yordayıcısı olduğunu saptamıştır. Konuyla ilgili olarak Çankaya ve arkadaşları (2012) tarafından yapılan bir çalışmanın sonucunda hayal gücünün, yaratıc düşünme ve değişime açıklık aracılığı üzerinde yüksek ve pozitif yönde bir etkisi olduğu sonucuna varılmıştır.

\section{Yaratıcılı̆̆ı Engelleyen Faktörler}

Bireylerin karşılaştıkları veya maruz kaldıkları olumlu faktörler (durumlar, şartlar vb.) doğuştan getirilen yaratıcılıkların geliştirdiği gibi olumsuz faktörler ise yaratıcıllğı köreltmekte veya en iyi ihtimalle var olan düzeyinde b1rakmaktadır. Bireysel ve toplumsal yapılar yaratıcılığın gelişmesini engelleyecek öğeler içerebilir. Tanımı ve nasıl geliştirildiği bilindikten sonra yaratıcllığı engelleyen faktörlerin tespit edilmesi zor değildir. Alanzyazında yaratıcllğg engelleyen temel faktörler ve bu faktörlerin özellikleri şöyle sıralanmaktadır (Rickards ve Jones, 1987; Akt: Erten Tatlı, 2017; Sungur, 1997; Sünbül, 2011; Ülgen, 1997; Rıza, 1999; Akt: Doğan, 2007; Üstündağ, 2003):

Algisal engeller: Problem alanını daraltma, problemin farkına varamama, gözlem becerisinin yetersizliği, kavramsal bilginin yetersizliği, ilişkileri görememe, değerlendirmede kullanılan ölçütleri seçememe, sebep-sonuç ilişkisini algılayamama vb. öğeleri içermektedir.

Duygusal engeller: Düşünme esnekliğinin olmayışı, eleştirilme veya hata yapma korkusu, tez canlılık, sabırsızlık, görüşler üzerinde ayrıntılı düşünmeme, bir an önce sonuca ulaşma isteği, bağımlılık, denetim korkusu, önyargılı olma, başarma korkusu, kendine güvensizlik, motivasyon öğelerine sahip olan bir engel türüdür.

Kültürel engeller: Farklı kültürler bazı konularda yaratıcılığı özendirir veya önünü açarken bazı konularda da yaratıcılığı engelleyebilir. Öğrenilen toplumsal alışkanlıklar ve töreler, kültürel engeller arasında yer alabilir. 
Öğrenilmiş engeller: Olaylara ya da nesnelere kalıp anlamlar yüklenmesi, nesneleri belirli bir biçimde kullanmaya alışma, tabular ve fobiler bu engellerdendir.

Yüklü program engelleri: Öğretim programlarının (derslerin) belirli bir zaman aralığında tamamlanma zorunluğu, konuların ve içeriğin üst üste yığılımı, bitirilmesi gerekir inancı veya zorunluluğu da yaratıcılı̆̆ önleyebilir.

Ego engeli: Belirli bir inanç kalıbıyla gelen güçlü ego, işleri daha da kötü duruma sürükleyebilir, insanları bu yanlış inançların saldırgan bir savunucusu olmaya itebilir. Bu durum ise hem kişiliğin oluşmasına hem de yaratıcılığa zarar verebilir.

Rutin davranış veya iş engelleri: Belli bir kalıpta yapılan rutin işler işler insanları da kalıplaşmış davranışlara sokabilir ve rutin davranmaya sevk edebilir. Bu durum yaratıcllğın aforoz konusunu teşkil eder ve insanlara "bürokratik bir akıl" dayatır.

Korku engelleri: İnsanlar kendilerini ifade etmekten veya başkalarının olumsuz yargılarından çekinebilir ki bu durum bireyin yaratıcılığını sınırlar.

Eğitsel engeller: Teorik olarak eğitim düzeyi yükseldikçe yaratıcılık düzeyinin de üst noktaya kadar yükselmesi beklenir. Ancak olumsuz eğitim ortamları yaratıcılığı düşürebilir. Eğitim ve akademik yaşamları boyunca yanılma ve başarısızlığın tehlikelerini gören, atlatan veya öğrenen fazla eğitim almış insanlar bir bakıma "cam tavan sendromu" nedeniyle daha az yaratıcı olabilir. Ancak şu unutulmamalıdır ki yaratıcılıkta onlarca, yüzlerce belki de binlerce defa yanılma ancak bir kez başarı vardır.

Stratejik engeller: Tek cevabın doğruluğunu kabul ederek, esneklikten uzaklaşmak olarak ifade edilebilir. Bireyin önceki öğrenmelerinden elde ettiği deneyimlerin sonuçlarını sorgulamadan doğru kabul etmesi yaratıcılığın önünde engel teşkil etmektedir.

Değer engelleri: Bireylerin sahip oldukları kişisel inançlar ve değerlere katı bağlılıkları yaratıcılığın önünde engel oluşturabilir. 
Algısal engeller: Bireylerin ilgilerinin ve odaklanmalarının dar bir alanda olması yaratıcı düşünmenin ortaya çıkmasını engelleyebilir.

Düşünce engelleri: Bireylerin kendi düşüncelerine güvenmemeleri ve düşüncelerini başkalarına aktarmaya çekinmeleri yaratıcılığı engelleyen başka bir faktördür.

\section{Düşünme ve Düşünce}

Osmanlıca'da "tefekkür", İngilizcede "thinking" kelimelerinin karşıllğı olan "düşünme" kavramı; ayırma, karşılaştırmalar yapma, bağlantıları birleştirme ve biçimleri kavrama yetisi olarak tanımlanmaktadır (TDK, 2019b). Dilsel semboller kanalıyla biçimlenen ve organize zihinsel sürecin ürünü olan düşünme kavramsal nitelikte olup dil aracilığıyla ortaya çıkmaktadır. Düşünme; deneyim, gözlem, sezgi, akıl yürütme ve diğer kanallarla edinilen bilgileri kavramsallaştırma, uygulama, analiz ve değerlendirmelerin disipline edilmiş şeklini ifade etmektedir. Düşünmeyi, var olan bilgilerden başka bir şeye ulaşma, başka bir şeyi elde etme ve edinilen bilgilerin ötesine ulaşma şeklinde tanımlamak da mümkündür (Aydın, 2000; Özden, 2005; Yıldırım, 2007).

Düşünme kavramı zaman zaman düşünce kavramı ile karıştırılmakta ve kavram yanılgısı ortaya çıkmaktadır. Düşünce; zamanın ve uzay ötesinde, öznenin dışında, kendiliğinden var olan, duyularla değil yalnızca ruhen alg1lanabilen asıl gerçeklik, mütalaa, fikir, ide, idea olarak tanımlanmaktadır (TDK, 2019c). Konuyla ilgili olarak Binbaşığlu (1994) düşünmeyi zihnin, bir konuyla ilgili bilgileri karşılaştırarak ve aralarındaki bağlantıları inceleyerek bir karar ya da yargıya varma süreci; düşünce ise düşünme sonucunda bilince doğan veya ortaya çıkan düşün, fikir, ürün olarak tanımlamaktadır. Düşünme Eğitimi Programı'nda düşünme, sonuca varmak için bilgileri, kavramları incelemek, karşılaştırmak ve aralarında bağlantı kurarak başka düşünceler üretmek işlemi; düşünce ise düşünme işlemleri sonucunda ortaya çıkan zihinsel ürün şeklinde tanımlanır (MEB, 2007). 


\section{Yaratıcı Düşünme}

Bireylerin karşılaştığı yeni durumlara farklı çözüm yolları sunmasında, etkili iletişim kurmasında ve kendilerini geliştirmek için faydalı fikirler, imkânlar veya alternatifler oluşturmasında yaratıcı düşünme becerisi önemli bir konu olarak dikkati çekmektedir (Karlıdağ, 2018). Yaratıcı düşünme; karşılanması gereken bir ihtiyacımızla ilgili, yeni fikirlerimize şekil verme becerisidir. Sorun ile ilgili gerekli kıstaslar göz önünde bulundurularak özgün, diğer bir deyişle yerinde ürünler veya sonuçlar elde etmedir (Kaya, 2008). Yaratıcı düşünme, bireylerin karşılaştığı problemleri sezerek içselleştirip, olaylar arasında neden-sonuç ilişkisini sağlayarak problemin çözümüne ilişkin çeşitli tahmin ve öneriler bulunup, bu problemlerin giderilmesi için alternatif çözümler üretip, sonuçları karşılaştırarak değişime açı çeşitli ürünler oluşturup, özgün ve yenilikçi bir bakış açısıyla alışılagelmişin dışına çıkma şeklidir (Üstündağ, 2014). Buluşçu yenilik peşinde olan ya da eski sorulara yeni çözümler sunan ve özgün düşüncelerin ortaya çımasına sebep olan bir düşünme şeklidir (Özden, 2005). Üst düzey bilişsel becerilerden biri olan yaratıc1 düşünme, ürün ortaya koyma, buluş yapma, yapılan bu buluşun nasıl olduğunu gösterme, varsayma, oluşturma, hayal etme, özgün düşüncelerin ortaya çıkmasını sağlama, farklı durumlarda neler olabileceğini öngörme becerilerini kapsamaktadır (Hançerlioğlu, 2000; Sternberg \& Grigorenko, 2004).

$\mathrm{Bu}$ tanımlar ve alanyazında yer alan diğer tanımlardan yola çıkılarak yaratıcı düşünmenin karakteristik özellikleri şöyle sıralanabilir (Alder, 2004; Akt: İnan \& Özgen, 2008): Düşünme esnekliği, düşünme akıcılığı, orijinallik, problemleri görebilme ya da problemlere karşı duyarlılık, yeniden tanımlama, belirsizliği tolere edebilme, ayrıntıya girme, yakınsak ve ıraksak düşünmeye ilgi, yüksek derecede öz disiplin, farklı olma ve geleneksele karşı koyma isteği, yüksek mükemmellik standardı, risk alma isteği, içinde bulunduğu duruma yenilik getirmesi. Yaratıclık ve yaratıcı düşünme farklı kavramlar olmasına rağmen zaman zaman birbirlerinin yerine kullanılan kavramlar olarak karşımıza çıkmaktadır. Yaratıcılık zihinsel ve performansa dayalı etkinlikleri çağrıştırırken yaratıı düşünme daha çok zihinsel etkinliklere işaret etmektedir. Yaratıcılık, yaratıcı düşünmeden daha kapsayıcı bir kavramdır (Doğan, 2007). Yaratıcı düşünme becerisine (yetisine, kazanımına) sahip olmak bireylerin yaratıclıklarına doğrudan etki etmektedir. 


\section{Yaratıcı Düşünmenin Gelişimini Kolaylaştıran Yollar}

Öğrencilerde yaratıcı düşünmeyi geliştirmenin yollarını beş boyutta ele alan Harris (1998; Akt: Doğanay, 2012) bu yolları ve yolların genel özelliklerini şu şekilde açıklamaktadır:

Evrim yöntemi: Çözülen sorunun daha iyi çözülebileceği fikri bu yöntemin özünü oluşturmaktadır. Eski düşüncelerin geliştirilmesiyle yeni düşünceler, eski ürünlerin geliştirilmesiyle de yeni ürünler olur. Kısaca yeni düşünceyi ve ürünü geliştirmenin yolu, onlara yeni işlevler yüklemekten geçmektedir. Örneğin, televizyonun öyküsü evrim yoluyla yaratıcllğa bir örnektir. Önceleri tüplü ve siyah beyaz olan televizyon, sonra renklendirildi, daha sonra da tüpsüz televizyon, LCD veya plazma televizyon üretildi. Bu bağlamda öğrencilere kullanılan ürünleri nasıl geliştirebilecekleri etkinliği yapılabilir. Örneğin; sınıfları, kitapları, arabaları, fotoğraf makinaları vb. aletleri nasıl geliştirebilecekleri sorusu sorularak, yantlar sözel, yazılı ya da proje olarak verilebilir.

Sentez yöntemi: Yaratıcılığı geliştirmek bir bakıma iki ya da daha fazla sayıda olan farklı şeyleri bir araya getirerek yeni bir ürün elde etmektedir. Bugün insanoğlunun kullandığı birçok araç birbiriyle ilişkili birkaç işlevin bir araya getirilmesi yani birleştirilmesiyle üretilmiştir. Radyo, MP3 çalar, bilgisayar, cep telefonları, fotoğraf makinası, telefon vb. aletlerin işlevlerinin birleştirilmesiyle üretilmiştir. Örnek etkinlik: “Aşağıdakilerden sadece ikisini kullanarak ne gibi yeni şeyler üretebilirsiniz?" Kay kay, çöp bidonu, merdiven, süpürge, çadır, boya fırçası, bahçe süpürgesi.

Devrim yöntemi: Kimi zaman eski ürün veya düşünceleri geliştirmek yerine, onlardan tamamen farklı işlevlere sahip olan yeni bir ürün üretmektir. Örneğin, elde pamuk toplama yerine, pamuk toplama makinasının geliştirilmesi. Bilginin yayılması ve saklanmasında kitap yerine internet kullanımı gibi. Örnek etkinlik: "Kitabın yerine kullanılacak ürün düşününüz?"

Yeniden uygulama yöntemi: Bir şeyi alışılmışın dışında farklı yollarla veya amaçlarla kullanmayı denemedir. Bunun için zihin ve düşünce yapısı itiba- 
riyle kalıp yargıları, önyargıları, beklentileri bir yana bırakıp farklı perspektiflerden bakmak gerekmektedir. Örnek etkinlik: “Boğaz Köprüsü farklı amaç ve yollarla nasıl kullanılabilir?"

Yön değiştirme yöntemi: Sorun veya duruma bakış açısını değiştirip bir açıdan diğer bir açıya geçişi ifade etmektedir. Amaç, belirli ve alışılmış bir yol uygulayarak sorunu çözmek değil sorunu çözmektir. Bazen sorunu çözmek için bilindik klasik görüş açılarının ya da çözüm yollarının dişına çıkmak gerekir. Örnek etkinlik: Belediye şehir trafiğinin sıkışması ve park sorunu nedeniyle yeni bir kapalı park yapmak istemektedir. Ancak yer sorunu vardır. Belediye meclis üyelerinin çoğu, şehir merkezindeki parkın, araba parkı hâline getirilmesini önermektedir; "Sorunun çözüm yolunu nasıl değiştirebilirsiniz?"

Iraksak düşünmeyi geliştirme yöntemi: Yaratıcılığı geliştiren ıraksak düşünme, denence hâline getirme ya da mümkün olan ve kantlarla desteklenebilen belirli sayıda yanıtı teşvik etme veya anlamlı sorular sorma anlamını taşır. Yakınsak düşünme yanıtı önceden belli sorulara odaklıdır. Iraksak düşünme ise özgün ya da yaratıcı birden çok yanıt gerektirir. Örnek: "Türkiye'nin başkenti neresidir?" (yakınsak soru). "Ankara neden başkent olarak seçilmiştir?" (rraksak soru).

\section{Yaratıcı Düşünmenin Gelişimini Kolaylaştıran Öğrenme-Öğretme Ortam- lan}

Yaratıcı düşünme; bilgi üretme ortamında ve günümüz bilgi çağında geliştirilmesi gereken önemli bir olgudur. Her birey yaratıcı düşünme becerisine ya da kapasitesine sahip bir şekilde dünyaya gelir (Isenberg ve Jalongo, 1993; Akt. Can Yaşar ve Aral, 2010). İçerisinde yaratıcılığın da yer aldığı doğuştan getirilen beceriler, içinde bulunulan çevresel şartlardan ve seçilen yaşam biçimlerinden etkilendiği için zengin deneyimler, özgür ortamlar, çeşitli hobi ve uğraşlar, farklı bakış açlarıyla yaratıclık becerisi geliştirilebilir (Gartenhaus, 2000; Hewett 2005; Akt: İnal Kızıltepe, Can Yaşar ve Uyanık, 2017; Kemple ve Nissenberg, 2000). Yaratıc düşünebilme becerisini kazanmak için bireylerde potansiyel olarak bulunan bu becerinin gelişiminin eğitimle desteklenmesi gerekmektedir (Yavuzer, 1994). Uygun çevre şartları ve eğitimle 
bireylerin yaratıcı düşünme becerileri keşfedilip geliştirilebilir (Argun, 2012). Nitekim sadece doğuştan getirilen beceri olarak kabul edilse dahi yaratıcllık aynı zamanda uygun koşullara sahip ve desteklenen çevresel ortamda geliştirilen özelliğe sahip olan bir beceridir. Uygun fiziksel çevre, öğrencilerin özelliklere uygun hazırlanmış destekleyici bir program ve bu konuda bilgili personel bu becerinin geliştirilmesinde önemli rol oynamaktadır (Şahintürk, 2012).

Özellikle eğitim ve eğitimin en önemli uygulama yer yeri olan öğrenmeöğretme ortamları, yaratıcılık ve yaratıcı düşünmenin gelişimindeki önemli faktörlerden birisidir. Sabit bir beceri olmayan yaratıcılık gelişme özelliğe sahiptir. Yaratıcllı̆ın ve yaratıcı düşünmenin gelişimi için öğrenme-öğretme ortam ve süreçlerinin bazı niteliklere sahip olması gerekmektedir. Bireylerin yaratıclıklarını geliştirmek veya ortaya çıkarmak için onlara yanlış yapma ve fikirlerini uygulama fırsatı sunmak gerekmektedir. Yaratıcı etkinlikler yapmak ve bu etkinliklere bireylerin katılması, onlarda var olan yaratıcı potansiyelin ortaya çıkmasını ve kendilerini ifade etmesini kolaylaştırır (Kovalenko \& Smirnova, 2015). Öğrenme-öğretme ortamları öğrencilere model yaratıc1lığı temsil eden kurmaca metinler, yaratıcılıkla özdeşleşen ve yaratıcı düşünmeyi örneklendiren tarihi şahsiyetler, bilim insanları, filozoflar, devlet adamları, sanatçılar vb. kişilerin biyografilerini okutmak, anlatmak, izletmek vb. öğrencileri yaratıcı düşünme yönünden motive etmeye ve başka hayatlardan esinlenmelerine yardımc olur (Demir, 2019).

Düşünmeyi içeren ve öğrencilerin ilgisine odaklanan öğrenme süreci, zengin uyaranlarla donatılmış çevre, açık uçlu sorular, farklıkların kabul görmesi, yeni şeyleri denemenin desteklenmesi yaratıcı düşünme becerisini destekleyen önemli unsurlar olarak görülmektedir (Freedman, 2010; Mellou, 1996). Yaratıcı olmak ve düşünmek için öncelikle bireylerin kendilerine güvenmesi, bağımsız düşünebilmesi, alışılmış kural ve kalıpların dışına çıması, öğrencinin kendini güvende hissetmesi, bireyin iç disiplinini kazanması ve becerilerini kullanabileceği ortamın sağlanması gerekmektedir (Can Yaşar ve Aral, 2011; Tok ve Sevinç, 2010). Yaratıcı düşünmeyi sağlamak amacıyla öğrenme-öğretme ortamında yapılması gerekenler, yaratıcı düşünmeye imkân veren bir sınıf ortamı özellikleri şu şekilde sıralanabilir (Feldhusen vd.; 1985; Akt: Aksoy, 2005): 
$\checkmark$ Televizyon, bilgisayar çeşitli araç-gereçlerle eğitim ortamı zenginleştirilmelidir.

$\checkmark$ Öğrenciler dinlenmeli, gülümsemeli, teşvik edici ve sıcak bir atmosfer oluşturmalıdır.

$\checkmark$ Konular ve içerik, merak uyandıracak, gerçek yasamla ilişki kuracak nitelikte olmalıdır.

$\checkmark$ Öğrenciler rahat davranış sergilemeli, fikirlerini açıklayabilmeli, özgür ve cesaretli olmalıdır.

$\checkmark$ Öğrencilerin rekabet yerine işbirlikli öğrenmesine öncelik verilmeli, hata yapmaları hoş görülmelidir.

$\checkmark$ Öğrenci-öğrenci, öğrenci-öğretmen arasında karşılıklı saygıya veya kabule dayan ilişki veya iletişim kurulmalıdır.

$\checkmark$ Öğrencilerin sorularına saygı duyulmalı, değişik bağlantılar kurmaları ve farklı düşünmeleri teşvik edilmelidir.

$\checkmark$ Yaratıcı performansı ve düşünmeyi geliştirmeye daha fazla uygun olan öğretim ve öğrenme yöntem ve teknikleri kullanılmalıdır.

$\checkmark$ Yaratıcı düşünme aşamaları ve ürünleri doğru değerlendirilmeli, tamamlayıcı ölçme ve değerlendirme yöntemleri de kullanılmalıdır.

$\checkmark$ Yaratıcı davranış veya ürünlerle ilgili yayınlar yapılmalı, sergiler açılmalı, bu tür davranış ve ürün ortaya koyan öğrenciler pekiştirilmeli veya ödüllendirilmelidir.

Çocukların gelişim özelliklerini ve ilgilerini merkeze alan; öğrencinin araştırıcılığına, problem çözmesine, etkinliğine önem veren; ilerlemecilik eğitim felsefesine uygun olan; öğrencinin ilgi, ihtiyaç ve kararlarını ön plana çıkaran bir öğretim programı, onun yaratıcılığını besler (Yenilmez ve Yolcu, 2007). Öğrenme-öğretme ortamları çocukların yaratıcı düşünme ve bu düşünmeyle ilintili olarak eleştirel, rraksak ve analitik düşünme gibi becerilerinin geliştirilmesine yardımcl; öğretim programlarının, öğrenme-öğretme ortamlarının, sınıf içi süreçlerin, eğitim materyallerinin vb. yaratıcı düşünmeyi destekleyici nitelikte olmalıdır (Üstündağ, 2014). Toplumların geleceğine yön veren öğretim programları (derslerin) ve öğretim programlarının uygulama alanı olan öğrenme-öğretme ortamları, yaratııllı̆ı toplumsal kalkınma için bir kültür şeklinde görmeli ve yaratıcılığı eğitim temel hedeflerinden birisi olarak ele almalıdır (Orhon, 2003). 
Öğretim programlarının bu işlevi yerine getirmesinde yani öğrencilerin yaratıcılık ve yaratıcı düşünme becerilerinin geliştirilmesinde ve eğitimin diğer temel amaçlarına ulaşılmasında öğrenme-öğretme ortamlarında (bir bakıma sürecinde) rol oynayan temel faktör, kullanılan öğretim ve öğrenme model, yöntem ve teknikleridir (Yeşilyurt, 2019a; 2019b; 2019c; 2019d; 2013). Öğretim model, strateji, yöntem ve teknikleri öğrencinin yaratıc düşünmelerinde ve fikir üretmelerinde bir pompa görevi yapmakta ancak kimseyi bir Picasso, Edison yapmayı amaçlamamaktadır. Bu noktada önemli olan öğrencilerin alışılmışın ötesinde daha özgün, yaratıcı düşünmelerini sağlayabilmektir.

Konuyla ilgili yapılan araştırmalar yaratıcılığın beyin fırtınası, yönlendirilmiş beyin firtınası, drama, gibi tekniklerin yanı sıra video oyunları, üç boyutlu yazılımlar ve sanal ortamlar gibi bilgisayar uygulamalarıyla geliştirilebileceğini kanıtlamaktadır (Can-Yaşar, 2009; İslim, 2009; Jackson vd., 2012; Ferguson, 2011; Liveri, Xanthacou ve Kaila, 2012). Alanyazın incelendiğinde teorik temelleri ve özellikleri dikkate alındığı zaman balık kılçı̆̆ı, yaratıcı drama, yaratıcı zıt düşünme, probleme dayalı öğrenme, problem çözme, beyin fırtınası, ters beyin firtınası, soru-cevap, tartışma, benzetim (similasyon), altı şapkalı düşünme, metafor, kavram haritası, zihin haritası, yaratıcılık grubu (sinektik), örnek olay incelmesi yöntem ve tekniklerinin yaratıcılı̆̆ı ve yaratıcı düşünmeyi daha fazla geliştirdiği söylenebilir (Açkgöz, 2006; Buzan, 2001; Demirel, 2012; Eker ve Sak, 2016; Karataş, Akçayır ve Tosik Gün, 2016; Koray, 2005; Onur ve Zorlu, 2017b; Özden, 2005; Özerbaş, 2011; Öztürk, 2004; Tuğrul, 2006; Yaman ve Yalçın, 2005). Öğrenme-öğretme ortam ve süreçlerinde kimi zaman bu ve benzeri yöntem ve teknikleri iç içe ya da birbirinin tamamlayıcısı olarak kullanmak da mümkündür.

\section{Yaratıcı Düşünmenin Gelişimini Kolaylaştıran Öğretmen Özellikleri}

Öğrencilerin yaratıcılığını ve yaratıcı düşünmelerini geliştirmenin en temel yollarından birisi başta öğretmen ve ebeveynler olmak üzere öğrenciye etki eden tüm paydaşların bu konuda ki model davranışlarıdır. Öğretmenler ve ebeveynler yaratıcılığı teşvik edici ortam sağlayabilirler. Yaratıcılığı modelleyerek öğrencilerin veya çocukların yaratıcılıklarının geliştirebilir, yaratıcılığın nasıl geliştiğini söyleyerek değil onlara göstererek daha etkili olabilirler (Sternberg, 2003; Sternberg ve Williams, 1996; Akt: Demir, 2019). Öte yandan 
hem model olabilmeleri hem de öğrencilerin yaratıcılıklarını geliştirebilmeleri için öncelikle öğretmenlerin yaratıcı ve yaratısı düşünme niteliğe sahip olması ve bu konuda kendilerini geliştirmesi gerekmektedir.

Yaratıı düşünme, eğlenceli, rahat, keyifli olan ve zaman baskısında uzak ortamda daha fazla geliştiği için öğretmen, baskıdan uzak durup öğrencilerin rahat oldukları, keyif aldıkları, demokratik bir öğretme-öğrenme ortamı oluşturmalıdır. Öğretim ve öğrenme süreci öğrencilerin istedikleri, ilgi duydukları, kendilerini hazır hissettikleri bir ders veya konuyla ilgili etkinliklere başlayıp sürdürülebilir. Öğretmen, öğrencilerin olağanın dışında çözüm bulmalarına ve özgürce deneme yapmalarına firsat tanıyarak esnek öğretme-öğrenme süreci veya ortamı düzenleyebilir (Özerbaş, 2011), zevkli sınıf ortamı oluşturabilir, dersi istendik duruma getirmek için ders materyallerini ve içeriği farklı şekillerde kullanılabilir.

Problem çözen, uyum sağlayan, değişik fikirleri dile getiren, derse ilgi çeken, yenilik içerisinde olan, motive eden, öğrenciyi özgün bir kişi kabul eden, model, mutlu ve heyecanlı olan, eşit davranan, başarıyı ödüllendiren, kolay iletişim kuran, öğrencileri tanıyan, çeşitli etkinlik yapan, demokratik davranan, özgürce denemeler yaptıran, olağanın dışında çözüm arayan, esnek öğretme-öğrenme ortam düzenleyen, yeniliğe önem veren, alternatif çözümler arayan, mesleğini seven, derse heyecan katan, konu ile yaşam arasında bağlantı kuran, konuları anlaşılır kılan, ıraksak soru soran, fikirleri dinleyen ve onlara değer veren, övgü yapan, cesaretlendiren, yumuşak ve nazik davranan, espri yapan, zaman zaman olaylara mizahi yönleriyle bakan vb. davranışları, rolleri veya görevleri yerine getiren veya sergileyen öğretmenler öğrencilerin yaratıcılıklarını ve yaratıı düşünmelerini daha fazla geliştirebilir (Çellek, 2001; İpşiroğlu,1993; Noyanalpan, 1993; Elliot,1991; Stephans ve Crawley, 1994; Akt: Öztürk, 2004; Kranyik ve Bartlett, 1965; Chambers, 1973; Akt: Schreglmann ve Kazancı, 2016; Özden, 2005).

\section{Yaratıcı Düşünmenin Gelişimini Kolaylaştıran Ebeveyn ve Çevrenin Özellikleri}

Yaratıc bireyin özelliklerinin tamamının her bireyde bulunamayacağı unutulmamalıdır. Gerekli ortam oluşturulduğu takdirde eğitim bireylerin bu özelliklerinin gelişmesine katkı sunabileceği gibi bireyler bu özellikleri eği- 
timle de kazanabilirler (Kurudayığlu ve Çetin, 2015). Aile ortamı, kişilik yapısı, eğitim sistemi ve okul, kültürel yapı vb. faktörler bireyin yaratıcılıklarında ve yaratıcı düşünme becerilerinin şekillendirilmesinde rol oynamaktadır. Bu faktörler, bireylerin doğuştan getirdiği yaratıcılık becerileri üzerinde "kartopu etkisi yaparak" bireylerin yaratıcılıklarını gelişmesini sağladığı gibi bu becerilerinin sönmesine, körelmesine de yol açabilir (Şahin ve Danışman, 2017).

Eğitim ortamları ve öğretmen, çocukların (öğrencilerin) yaratıcı düşünme becerilerini bir noktaya kadar geliştirebilir. Ancak unutulmamalıdır ki her yaştaki bireylerin, özellikle de küçük yaşlardaki çocukların yaratıcı düşünmelerinde başta aile olmak üzere kültürel, çevre ve sosyo-ekonomik şartların da büyük etkisi olduğu kabul edilmektedir. Bu noktada Dilek (2013), ailenin sosyo-kültürel grubu, ekonomik durumu, çevresel şartlar, etrafında konuşulan konular, okul, arkadaş grubu vb. değişkenlerin çocuğun zihinsel gelişimini ve yaratıcı düşünme becerilerini büyük ölçüde etkilediğini belirtmektedir.

Yaratıcı bireyler, yaratıcılık ile aile ilişkisi konularında yapılan bazı araştırmalardan şu sonuçlar elde edilmiştir (Aydın, 2011; Emir, Erdoğan ve Kuyumcu, 2007): Yaratıcı bireylerin genelde ilk veya ailenin en fazla ilgilendiği çocuk olduğu; kültürel veya entelektüel ev ortamı zenginliğinin çocukların yaratıcılıklarını olumlu etkilediği; genellikle orta veya üst sosyo-ekonomik yapıya sahip aile çocuklarının yaratıcı düşünme becerilerinin daha yüksek olduğu; demokratik ailelerde yetişen çocukların yaratıcılık puanlarının otoriter ailelerde yetişen çocuklara göre daha fazla olduğu; üst düzeyde yaratıc1 bireylerin daha fazla kardeş sahibi olduğu; yaratıcı olarak nitelendirilen bilim insanlarının babalarını genellikle küçük yaşta kaybettikleri sonuçlarına ulaşılmıştır.

Konuyla ilgili yapılan araştırmalar ve kuramsal bilgiler, çocukların yaratıcılıklarında ve yaratıcı düşünmelerinde aile ve çevrenin ne kadar önemli olduğunu somut olarak ortaya koymaktadır. Bilinçli ebeveynler daha okul öncesi dönemde çocuklarına yaratıcı niteliklerini geliştirici uyarıcılar sunar, onların düşünce ve etkinliklerinde özgür olmalarını sağlar, saygı ve hoşgörüye dayalı aile ve çevresel bir ortam oluşturarak çocukların yaratıcılığa yönelik gizil güçlerini sergilemelerine veya ortaya çıarmalarına yardımcı olurlar (Çeliköz, 2017). 
Yaratıcı düşünmeyi destekleyici aile ortamı; karar verme, deneyimleme ve keşfetme için hem özgürlük hem de psikolojik güvenlik sunarak çocukların fikirlerini paylaşabilmelerini sağlayabilir, yeni fikirlerle risk üstlenmesini cesaretlendirerek bağımsızlığı teşvik edebilir, esnek ve yaratıcı rol modelleri sunarak daha fazla zenginleşmiş öğrenme ortamı sağlayabilir (Kemple ve Nissenberg, 2000). Ailede, kabul edici, duyguların rahatlıkla ifade edildiği bir ortam yaratılarak yaratıcı düşünme becerilerinin gelişmesine katkıda bulunulabilir. Ailenin destekleyici tutumu, çocukta var olan yaratıcı düşünme becerisinin gelişmesine yardımcı olmaktadır. Çocuklar yaratıcı davranışları ilk kez evde deneyimler, bunları anne-babalarını izleyerek, model alarak geliştirirler. Yaratıcllı̆ga izin veren aileler, çocuğun bakış açısına değer vererek onun fikirlerini aile kararlarında kullanırlar. Böylece çocuğun başkalarının bakış açısını görmesine yardımcı olurlar (Sungur, 1997).

Öğretmenler gibi ebeveynlerin veya birlikte yaşadığı diğer kişilerin de çocuklara model olması; çocuğa cinsiyetine, becerisine ve yaşına uygun görev ve sorumlukların verilmesi; yaratıcılık eğitiminin ilk olarak başladığı yer ve kurum olan ailenin bu konudaki görevleri yerine getirmeye gayret ettiğini göstermektedir (Ömeroğlu \& Kandır, 2005). Çocuklarına karşı ilgi ve saygı göstermek; gelişim dönemi özelliklerini bilmek, tanımak, kabul etmek ve bu özelliklere uygun davranmak; destek sağlamak ve şefkat göstermek; ilgi alanlarına ve isteklerine saygı göstermek; çeşitli etkinlikler yapmak; zaman ayırmak; etkili iletişim kurmak; soru sorma, sorgulama ve eleştiri yapmalarına fırsat tanımak; söz hakkı vermek; karar ve planlara katmak vb. davranışları sergileyen aileler, çocukların daha yüksek düzeyde yaratıcı davranışlar sergilemesine ve yaratııı düşünme becerisine sahip olmasına katkı sunabilirler.

\section{Sonuç}

Yaratıclık ve yaratıcı düşünme doğuştan getirilen ayn zamanda doğum sonrasında olumlu çevre şartları altında geliştirilen, olumsuz çevre şartları altında durağanlaşan ya da körelen bir beceri olarak kabul edilmektedir. Elbette birey, toplum ve devletler bu becerinin gelişmesini istemektedir veya istemelidir. Ekonomi, bilim, sanayi, teknoloji, tarım, ticaret vb. birçok alanda gelişimin hızla yaşandığı günümüz dünyasında bireylerin yaratıcılık ve yaratıcı düşünme becerileri geçmiş dönemlere göre daha fazla ön plana çıkmakta ve önemini giderek artırmaktadır. Bireylerin yaratıclıkları ve yaratıcı 
düşünme becerilerinin gelişmesinde aile, sosyal, psikolojik ve fiziksel çevre, okul, öğretim programları (dersler), öğretmen, medya, iletişim araçları, çeşitli bilgi kaynakları gibi birçok faktör etki etmektedir. Bu faktörlerin bilinçli ve ortak hareket etmeleri, yaratıcılık ve yaratıcı düşünmenin gelişimi açısından önem arz etmektedir. Bunun sağlanabilmesi için başta aile, öğretmen, çevre olmak üzere yaratıcılık ve yaratıcı düşünme üzerinde etkili olan tüm faktörlerin yaratıcılık ve yaratıc düşünme hakkında genel ve temel bilgiye sahip olması gerekmektedir.

Yaratıcılık ve yaratıcı düşünme, ülkemizin de içerisinde yer aldığı birçok ülkenin öğretim programlarının genel amaçları arasında yer almaktadır. Artık ülkelerin birbirleriyle sosyal, ekonomik, bilim, teknoloji, kültürel, askeri vb. alanlardaki yarışlarını ve daha önemlisi bu alanlarda bir ülkenin kalkınmasını, o ülkenin eğitim sistemlerinin bir çıkısı olan öğrencilerin yaratıcı ve yaratıcı düşünme becerisine sahip birey olmalarıyla mümkün olmaktadır. $\mathrm{Bu}$ bağlamda yaratıcılık ve yaratıcı düşünme becerilerine sahip olmanın, bu becerileri açı̆̆a çıkarmanın, fark etmenin ve kullanmanın öncü şartlarından birisi, ilgili kavramların kapsayıcı nitelikte ve teorik bir bütün halinde ele alınması ve bilinmesidir.

Bu çalışma kapsamında alanyazında yer alan ve konuyla ilgili olan kitap, kitap bölümü, makale, tez vb. birçok çalışma incelenmiştir. Yaratıcılık veya yaratıcı düşünme konusuyla ilgili olan ve farklı kaynaklarda yer alan temel ve genel bilgiler;

$\checkmark$ Yaratıcilik,

$\checkmark$ Yaratıcılık yaklaşımları,

$\checkmark$ Yaratıc bireyin özellikleri,

$\checkmark$ Yaratıcılıkla ilgili yanlış anlaşılmalar,

$\checkmark$ Yaratıcılığın boyutları,

$\checkmark$ Yaratıcılı̆̆ın aşamaları,

$\checkmark$ Yaratıcılıkla anlamlı ilişkisi olan faktörler,

- Yaratıcilik ve zekâ,

- Yaratıcilık ve yaş,

- Yaratıcilik ve beyin,

- Yaratıclik ve iraksak düşünme,

- Yaratıcilık ve hayal gücü,

$\checkmark$ Yaratıcılığı engelleyen faktörler,

$\checkmark$ Düşünme ve düşünce, 
$\checkmark$ Yaratıcı düşünme,

$\checkmark$ Yaratıcı düşünmenin gelişimini kolaylaştıran yollar,

$\checkmark \quad$ Yaratıcı düşünmenin gelişimini kolaylaştıran öğrenme-öğretme ortamları,

$\checkmark \quad$ Yaratıcı düşünmenin gelişimini kolaylaştıran öğretmen özellikleri,

$\checkmark \quad$ Yaratıcı düşünmenin gelişimini kolaylaştıran ebeveyn ve çevrenin özellikleri alt başlıkları şeklinde derlenmiş ve açıklanmıştır.

"Yaratıcllk ve yaratıcı düşünme el kitapçı̆̆ı" niteliğinde olan bu çalışmanın başta öğretmen, aile ve öğrenciler olmak üzere ilgili paydaşlara bir kılavuz olacağı, yaratıcılık ve yaratıcı düşünmenin gelişimine katkı sağlayacağı düşünülmektedir. 


\title{
EXTENDED ABSTRACT
}

\section{Creativity and Creative Thinking: A Comprehensive Review Study with All Dimension and Stakeholders}

\author{
Etem Yeşilyurt \\ Akdeniz University
}

Creativity and creative thinking are considered as innate skills developed under positive environmental conditions, stagnating or dulling under negative environmental conditions. Creativity and creative thinking skills, which can be improved with education, have taken their place among the general aims of education in our country. Many factors especially such as family and social and physical environment, school, curriculum, teacher etc. affect the development of individuals' creativity and creative thinking skills. This review study was conducted in order to compile and present the basic information in the literature about creativity and creative thinking.

First of all, definitions related to creativity concept were given and the approaches that originated from these definitions were examined in the scope of the study. It is difficult to make a precise definition of creativity. The relevant definitions say that creativity is a complex way of thinking; and they place emphasis on the concepts of new, innovation, originality and invention. Then, features of creative individual, misunderstandings about creativity, dimensions and stages of creativity were given. The dimensions of creativity are rational approach, personality and individual characteristics, lifestyle, unreasonable side, and social-interpersonal factors. Curiosity, ability to make inventions, patience, adventurous thinking, daydreaming, thinking with images, traits that don't avoid experiments and researches and that can reach synthesis judgments constitute the fundamental features of creative individuals. The judgments such as that creativity is only in certain areas and it requires a high level of talent and intelligence; creative people create creative products without any effort; and that creative people are mentally unstable are among the basic misunderstandings about creativity. While fluency, flexibility, originality and elaboration are the dimensions of creativity; preparation, incubation, introversion and evaluation form its stages. Intelligence, age, brain, divergent thinking and imagination are among the factors that have a 
significant relationship with creativity. The factors that prevent creativity perceptual, emotional, loaded program; routine behavior or work; fear and, educational, strategic, perceptual and thought barriers.

On the other hand, definitions of thinking and thought concepts are given and information about creative thinking which is one of the high level thinking skills is presented. Thinking is the process of making a decision or a judgment by comparing information on a subject and examining the connections between them; and thought is defined as thought, idea, product that arises or arises from consciousness as a result of thinking. Creative thinking includes producing products, making inventions, showing how the invention is made, assuming, creating, imagining, enabling the emergence of original thoughts, and predicting what might happen in different situations. Evolution, synthesis, revolution, reapplication, changing direction and developing divergent thinking are considered ways to facilitate the development of creative thinking. In addition, the ways of facilitating the development of creative thinking, learning-teaching environments, teacher characteristics are mentioned, and the duties of parents and the environment to develop and support creativity are explained.

Many factors such as family, social, psychological and physical environment, school, education programs (lessons), teacher, media, communication tools and various sources of information affect the development of individuals' creativity and creative thinking skills. The conscious and collective action of these factors is important for the development of creativity and creative thinking. In order to achieve this, all factors affecting creativity and creative thinking, especially family, teacher, environment, should have general and basic knowledge about creativity and creative thinking.

Creativity and creative thinking, which differ from innovation and change, are among the main objectives of the curriculum of many countries, including our country. Now, the countries' races in social, economic, scientific, technological, cultural, military, etc. fields their and more importantly, the development of a country in these fields is possible with the creative students who are the outputs of the education systems of these countries. In this sense, one of the leading conditions of having creativity and creative thinking skills, exposing, recognizing and using these skills is to consider and know the related concepts as an inclusive and theoretical whole. 
Within the scope of this study, relevant books, book chapters, articles, theses, etc. relating to the issue have been reviewed. Fundamental and general information about creativity or creative thinking that are located in different sources are as below:

$\checkmark$ Creativity,

$\checkmark$ Creativity approaches,

$\checkmark$ Characteristics of the creative individual,

$\checkmark$ Misunderstandings about creativity,

$\checkmark$ The dimensions of creativity,

$\checkmark$ The stages of creativity,

$\checkmark$ Factors that have a meaningful relationship with creativity,

- Creativity and intelligence,

- Creativity and age,

- Creativity and the brain,

- Creativity and divergent thinking,

- Creativity and imagination,

$\checkmark$ Factors that hinder creativity,

$\checkmark$ Thinking and thinking,

$\checkmark$ Creative thinking,

$\checkmark$ Ways that facilitate the development of creative thinking,

$\checkmark$ Learning-teaching environments that facilitate the development of creative thinking,

$\checkmark$ Teacher features that facilitate the development of creative thinking,

$\checkmark$ Features of the parent and the environment that facilitates the development of creative thinking.

It is hoped that this study which can be considered as "a brief handbook of creativity and creative thinking" will contribute to the literature, the creativity of individuals and the development of creative thinking skills.

\section{Kaynakça / References}

Açıkgöz, K. Ü. (2006). Aktiföğrenme. İzmir:Biliş Yayınclık.

Akar Gençer, A. (2014). Reggio Emilia temelli projelerin anaokuluna giden çocuklarm yaratıcı düşünme becerilerine etkisinin incelenmesi. Yüksek lisans tezi, Hacettepe Üniversitesi, Eğitim Bilimleri Enstitüsü. 
Aksoy, G. (2005). Fen eğitiminde yaratıcı düşünme temelli bilimsel yöntem sürecinin ögrrenme ürünlerine etkisi. Yüksek lisans tezi, Zonguldak Karaelmas Üniversitesi, Sosyal Bilimler Enstitüsü.

Argun, Y. (2012). Okul öncesi dönemde yaratıcllk ve eğitimi. Ankara:Anı Yayıncılık. Arıoğlu, E. (1999). Yaratıcı düşünce ve eğitim. 10.11.2019 tarihinde http://www.arioglu.net/bildiriler/yaraticidusunceveegitim.pdf adresinden erişilmiştir.

Aslan, E. (2001a). Torrance yaratıcı düşünce testi'nin Türkçe versiyonu, M.Ü. Atatürk Eğitim Fakültesi Ĕ̆itim Bilimleri Dergisi, 14, 19-40.

Aslan, E. (2001b). Kavram boyutunda yaratıcılık, Türk Psikolojik Danışma ve Rehberlik Dergisi, 2(16) , 15-21.

Aydın, A. (2000). Gelişim ve öğrenme psikolojisi, İstanbul:Alfa Yayınclık.

Aydın, Z. (2011). İköğretim 6. sinıf matematik dersinde kullanılan aktiföğrenme temelli etkinliklerin öğrencilerin matematik dersine karşı tutumlarına, akademik başarı ve yaratıcı düşünme düzeylerine etkisi. Yüksek lisans tezi, Gaziantep Üniversitesi, Sosyal Bilimler Enstitüsü.

Aydoğdu, Ü. R., Karamustafaoğlu, O. ve Bülbül, M. Ş. (2017). Akademik araştırmalarda araştırma yöntemleri ile örneklem ilişkisi: Doğrulayıcı doküman analizi örneği, Z.G. Eğitim Fakültesi Dergisi, 30, 556-565.

Bessis, P. ve Jaqui, H. (1973). Yaratıcllk nedir? (Çev. S. Gürbaşkan), İstanbul:İstanbul Reklam Yayınları.

Binbaşıŏlu, C. (1994). Genel öğretim bilgisi, Ankara, Kadığlu Matbaası.

Birgin, O. (2016). Matematik eğitiminde teoriler (Ed. E. Bingölbali, S. Arslan ve İ. Ö. Zembat), Bloom taksonomisi içinde (s.839-860), Ankara, Pegem Akademi.

Bloom, B. S. (Ed.), Engelhart, M. D., Furst, E. J., Hill, W. H. ve Krathwohl, D. R. (1956). Taxonomy of educational objectives: The classification of educational goals, Handbook 1: Cognitive Domain, New York:David McKay.

Bogoyavlenskaya, D. B. (2013). Nature of changes in creativity scores in preschool and junior schoolchildren, Procedia Social and Behavioral Sciences, 86, 358362.

Bolen, L. M. ve Torrance, E. P. (1978). The influence on creative thinking of locus of control, cooperation and sex. Jurnal of Clinical Psychology, 34(4), 903907.

Brophy, D. R. (2000). Comparing the attributes, activities, and performance of divergent, convergent, and combination thinkers, Creativity Research Journal, 13(3\&4), 439-455. 
Buzan, T. (2001). The power of creative intelligence (Yaratıcı zekânın gücü; Çev. B. Kurt, 2004), İstanbul:Epsilon Yayıncilık.

Can Yaşar, M. ve Aral, N. (2010). Yaratıcı düşünme becerilerinde okul öncesi eğitimin etkisi, Kuramsal Eğitimbilim, 3(2), 201-209.

Can Yaşar, M. ve Aral, N. (2011). Altı yaş çocuklarının yaratıcı düşünme becerilerine sosyo-ekonomik düzey ve anne baba öğrenim düzeyinin etkisinin incelenmesi, Kuramsal Ĕ̆itimbilim, 4(1), 137-145.

Can Yaşar, M. (2009). Anasınıfına devam eden altı yaş çocuklarının yaratıcı düşünme becerilerine drama eğitiminin etkisinin incelenmesi. Doktora tezi, Ankara Üniversitesi, Fen Bilimleri Enstitüsü.

Craft, A. (2003). Creative thinking in the early years of education, Early Years: An International Journal of Research and Development, 23(2), 143-154.

Cronbach, J. L. (1970). Essentials of psychological testing, New York, Harper and Row Publishers.

Çankaya, İ., Yeşilyurt, E., Yörük, S. ve Şanlı, Ö. (2012). Öğretmen adaylarında yaratıcı düşünmenin yordayıcısı olarak değişime açıklık ve hayal gücü, Uşak Üniversitesi, Sosyal Bilimler Dergisi, 5(2), 46-62.

Çeliköz, N. (2017). Okul öncesi dönem 5-6 yaş çocukların yaratıcılık düzeylerinin incelenmesi, YILDIZ Journal of Educational Research, 2(1), 125.

Çellek, T. (2001) Yaratıcılık: Eğitim sistemindeki boyutu, Cumhuriyet Bilim ve Teknik Dergisi, 741, 18-19.

Demir, A. (2019). Çocuk edebiyatı ve yaratıcı düşünme. idil, 60, 1011-1024.

Demirel, Ö. (2012). Eğitimde program geliştirme: Kuramdan uygulamaya, Ankara, Pegem Akademi.

Dere, Z. (2017). Yaratıcılık ve geliştirilmesi dersinin öğretmen adaylarının yaratıcllıklarına etkisinin incelenmesi. Social Sciences Studies Journal, 3(10), 1192-1199.

Dietrich, A. (2004). The cognitive neuroscience of creativity, Psychonomic Bulletin and Review, 11(6), 1011-1026.

Dilek, A. N. (2013). Sosyo-kültürel özelliklerin yaratıcı düşünmeye etkisi, Yüksek lisans tezi, Osmangazi Üniversitesi, Eğitim Bilimleri Enstitüsü.

Doğan, N. (2007). Eğitimde yeni yönelimler (Ed. Ö. Demirel), Yaratıcı düşünme ve yaratıcılık içinde (s. 167-192), Ankara, Pegem A Yayıncılık.

Doğanay, A. (2012). Öğretim ilke ve yöntemleri (Ed. A. Doğanay), Üst düzey düşünme becerilerinin öğretimi içinde (s. 303-356), Ankara, Pegem Akademi Yayınları.

Duman, B. (2011). Öğretim ilke ve yöntemleri (Ed. G. Ocak), Eğitimde çă̆daş yaklaşımlar içinde (s. 337-441), Ankara, Pegem Akademi. 
Duran, C. ve Saraçoğlu, M. (2009). Yeniliğin yaratıcılıkla olan ilişkisi ve yeniliği geliştirme süreci, Yönetim ve Ekonomi, 16(1), 57-71.

Eker, A. ve Sak, U. (2016). Yaratıcı zıt düşünme tekniğinin (yazıd) sosyal geçerliği, Türk Üstün Zekâ ve Ĕ̆itim Dergisi, 6(2), 71-87.

Emir, S., Erdoğan, T. ve Kuyumcu, A. (2007). Türkçe öğretmenliği öğrencilerinin yaratıcı düşünme düzeyleri ile sosyo-kültürel özelliklerinin ilişkisi, H.A. Yücel Ĕ̈̆itim Fakültesi Dergisi, 7(1), 73-87.

Ercivan Zencirci, D. (2008). Görsel sanatlar öğretmeni adaylarında özgün baskının yaratıcı düşünme becerileri ve öz-yeterlik algısı üzerindeki yansıması. Doktora tezi, Dokuz Eylül Üniversitesi, Eğitim Bilimleri Enstitüsü.

Ersoy, E. ve Başer, N. 2009). İlköğretim 6. sınıf öğrencilerinin yaratıcı düşünme düzeyleri, Uluslararası Sosyal Araştırmalar Dergisi, 2(9), 128-137.

Erten Tatlı, C. (2017). Çocuklarda yaratıcı düşünme becerilerinin saptanması ve okul psikolojik danışmanlarının farkındalı̆̆ının incelenmesi, Doktora tezi, Ankara Üniversitesi, Eğitim Bilimleri Enstitüsü.

Ferguson, R. (2011). Meaningful learning and creativity in virtual worlds, Thinking Skills and Creativity, 6(3), 169-178.

Freedman, K. (2010). Rethinking creativity: A definition to support contemporary practice, Art Education, 63(2), 8-15.

Gizir Ergen, Z. ve Köksal Akyol, A. (2012). Anaokuluna devam eden çocukların yaratıcılıklarının incelenmesi, Kuramsal Ĕ̈itimbilim Dergisi, 5(2), 156-170.

Güngör, İ. (2007). Anadolu Lisesi öğrencilerinin yaratıcı düşünme düzeylerinin kişisel uyum, sosyal uyum, genel yetenek ve akademik başarı ile ilişkisi, Yüksek lisans tezi, Ankara Üniversitesi, Eğitim Bilimleri Enstitüsü.

Hançerlioğlu, O. (2000). Felsefe ansiklopedisi: Kavramlar ve akımlar-7. İstanbul:Remzi Kitabevi.

Herdman, E. A. (2006). Derleme makale yazımında, konferans ve bildiri sunumu hazırlamada pratik bilgiler (Çev. Z. Dörtbudak), Hemşirelikte Eğitim ve Araştırma Dergisi, 3(1), 2-4.

İnal Kızıltepe, G., Can Yaşar, M. ve Uyanık, Ö. (2017). Bilişsel becerileri destekleme programını 61-72 aylık çocukların yaratıc düşünme, akademik ve dil becerilerine etkisi, Hacettepe Üniversitesi Ĕ̆itim Fakültesi Dergisi, 32(3), 612-629.

İnan, C. ve Özgen, K. (2008). Matematik öğretmen adaylarının öğretmenlik uygulaması sürecinde öğrencilere düşünme becerilerini kazandırmadaki yeterliliklerine yönelik görüşlerinin değerlendirilmesi, Elektronik Sosyal Bilimler Dergisi, 7(25), 39-54. 
İslim, Ö. F. (2009). Bilgi ve iletişim teknolojileri dersinin scamper (yönlendirilmiş beyin fırtınası) tekniğine göre işlenmesinin öğrencilerin yaratıcı problem çözme becerilerine ve akademik başarılarına etkisi. Yüksek lisans tezi, Gazi Üniversitesi, Eğitim Bilimleri Enstitüsü.

Jackson, L. A., Witt,E. A., Games,A. I., Fitzgerald, H. E., von Eye, A. ve Zhao, Y. (2012). Information technology use and creativity: Findings from the children and technology project, Computers in Human Behavior, 28(2),370-376.

Jensen, E. (1998). Teaching with the brain in mind, Virginia: Association for Supervision and Curriculum Development.

Kale, N. (1994). Eğitim ve yaratıcılık, Yaşadıkça Ĕ̆itim, 37 ,4-6.

Kanlı, E. (2017). Üstün yetenekli öğrencilerin bilimsel yaratıcılık düzeyleri, cinsiyet ve bilimsel tutumları arasındaki ilişkilerin incelenmesi, İlköğretim Online, 16(4), 1792-1802.

Kara, Ş. ve Şençiçek, S.(2015). Yaratıcı çocuk yetiştirmede problemler ve çözüm önerileri, Adnan Menderes Üniversitesi Ĕ̆itim Bilimleri Dergisi, 6(2), 90-97.

Karabey, B. ve Yürümezoğlu, K. (2015). Yaratıcılık ve üstün yetenekliliğin zekâ kuramları açısından değerlendirilmesi, Buca Eğitim Fakültesi Dergisi, 40, 86-106.

Karataş, S. ve Özcan, S. (2010). Yaratıcı düşünme etkinliklerinin öğrencilerin yaratıcı düşünmelerine ve proje geliştirmelerine etkisi, Ahi Evran Üniversitesi Ĕ̆itim Fakültesi Dergisi, 11(1), 225-243.

Karataş, S., Akçayır, G. ve Tosik Gün, E. (2016). Yaratıcı düşünme becerisini geliştirilmesinde ters beyin fırtınası tekniğinin etkililiği üzerine nitel çalişma, Ĕ̆itim Teknolojisi Kuram ve Uygulama, 6(1), 42-58.

Karlıdağ, İ. (2018). Okul öncesi öğretmenlerinin yaratıcılık kavramına ilişkin görüşleri, Uluslararası Sosyal Araştırmalar Dergisi, 11(56), 362-369.

Kaya, B. (2008). Sosyal bilgiler öğretmen adaylarının düşünme becerilerinin öğretimine yönelik öz-yeterliklerinin değerlendirilmesi, Doktora tezi, Gazi Üniversitesi, Eğitim Bilimleri Enstitüsü.

Kemple, K. M. ve Nissenberg, S. A. (2000). Nurturing creativity in early childhood education: Families are part of it. Early Childhood Education Journal, 28(1), 6771.

Koray, Ö. (2005). Altı düşünme şapkası ve nitelik sıralama tekniklerinin fen derslerinde uygulanmasına yönelik öğrenci görüşleri, Kuram ve Uygulamada Ĕ̆itim Yönetimi, 43, 379-400.

Kovalenko, N. A, ve Smirnova, A. Y. (2015). Self-directed learning through creative activity of students, Procedia-Social and Behavioral Sciences, 166, 393-398. 
Kurudayığlu, M. ve Çetin, Ö. (2015). Temel beceriler ve Türkçe öğretimi, Ana Dili Eğitimi Dergisi, 3(3), 1-19.

Leboutillier, N. ve Marks, D. F. (2003). Mental imagery and creativity: A metaanalytic review study, British Journal of Psychology, (94), 29-44.

Liveri, A., Xanthacou, Y. ve Kaila,M. (2012). The google sketch up software as a tool to promote creativity in education in Greece, Procedia-Social and Behavioral Sciences, 69, 1110-1117.

Maba, A. (2019). Güncel yaklaşımlar çerçevesinde müziksel yaratıcılık ve değerlendirilmesi, Turkish Studies Educational Sciences, 14(3), 681-697.

MEB. (2007). Düşünme eğitimi dersi 6,7,8. sımı öğretmen kılavuz kitabı, Ankara, MEB Yayınları.

Mellou, E. (1996). Can creativity be nurtured in young children? Early Child Development and Care, 119(1), 119-130.

Onur, D. ve Zorlu, T. (2017a). Yaratıcılık kavramı ile ilişkili kuramsal yaklaşımlar, Insan ve Toplum Bilimleri Araştırmaları Dergisi, 6(3), 1535-1552.

Onur, D. ve Zorlu, T. (2017b). Tasarım stüdyolarında uygulanan eğitim metotları ve yaratıcllı ilişkisi, The Turkish Online Journal of Design, Art and Communication, 7(4), 542-555

Onur, D. ve Zorlu, T. (2018). Tasarım eğitiminde duyusal farkındalık ve yaratıcllık ilişkisi üzerine (1), METU Journal of the Faculty of Architecture, 35(2), 89-118.

Orhon, G. (2003). Yine yazı yazıyoruz: Okulda, işyerinde, evde, kullanılabilecek yaratıcı yazı uygulamaları, Ankara:Pegem Akademi Yayıncılık.

Orhon, G. (2014). Yaratıcılık: Nörofizyolojik, felsefi ve eğitsel temeller, Ankara, Pegem Akademi.

Ömeroğlu, E. ve Kandır, A. (2005). Bilişsel gelişim, İstanbul, Morpa Yayınları.

Özden, Y. (2005). Öğrenme ve öğretme, Ankara:Pegem A Yayıncılık.

Özerbaş, M. A. (2011). Yaratıcı düşünme öğrenme ortamının akademik başarı ve bilgilerin kalıcılığa etkisi, Gazi Eğitim Fakültesi Dergisi, 31(3), 675-705.

Öztürk, Ş. (2004). Eğitimde yaratıcı düşünme, Ondokuz Mayıs Üniversitesi Eğitim Fakültesi Dergisi, (18), 77-84.

Rawat, K. J., Qazi, W. ve Hamid, S. (2012). Creativity and education, Academic Research International, 2(2), 264-275.

Rıza, E. T. (2000). Kalıplaşma ve yaratıcılık, Yaşadıkça Ĕ̆itim, 65, 4-7.

Saban, A. (2004). Öğrenme öğretme süreci: Yeni teori ve yaklaşımlar, Ankara:Nobel Yayın Dağıtım.

San, İ. (2004). Sanat ve eğitimi: Yaratıcılık, temel sanat kuramları, sanat eleştirisi yaklaşımları, Ankara:Ütopya Yayınları. 
Schreglmann, S. ve Kazancı, Z. (2016). Öğretmen adaylarının yaratıc öğretmen kavramına yönelik metaforik algıları, Üstün Zekâhllar Ĕ̆itimi ve Yaratıcıllk Dergisi, 3(3), 21-34.

Shaheen, R. (2010). Creativity and education, Creative Education, 1(3), 166-169.

Starko, A. J. (2010). Creativity in the classroom: Schools of curious delight, New York, Routladge Madison Ave.

Sternberg, R. J. ve Grigorenko, E. I. (2004). Successful intelligence in the classroom, Theory into Practice, 43(4), 274-280.

Sungur, N. (1997). Yaratıcı düşünce, Ankara, Evrim Yayınevi.

Sünbül, A. M. (2011). Öğretim ilke ve yöntemleri, Konya, Eğitim Kitabevi.

Şahin, F. ve Danışman, Ş. (2017). Yaratıcı kişilik özellikleri ölçeği: Güvenilirlik ve geçerlik çalışması, Karabük Üniversitesi Sosyal Bilimler Enstitüsü Dergisi, $7(2), 747-760$.

Şahintürk, Ö. (2012). Montessori yönteminin okul öncesi dönemde öğrencilerin yaratıcı düşünmelerine etkisi, Yüksek lisans tezi, Karaelmas Üniversitesi, Sosyal Bilimler Enstitüsü.

Taşpınar, M. (2012). Öğretim ilke ve yöntemleri, Ankara, Elhan Kitap.

TDK. (2019a). Yaratıcilk, 19.11.2019 tarihinde https://sozluk.gov.tr/ adresinden erişilmiştir.

TDK. (2019b). Düşünme, 21.11.2019 tarihinde_https://sozluk.gov.tr/ adresinden erişilmiştir.

TDK. (2019c). Düşünce, 21.11.2019 tarihinde https://sozluk.gov.tr/ adresinden erişilmiş̧ir.

Tekin, M. (2008). Orta öğretimde öğrenim gören öğrencilerden spor yapan ve yapmayanlar arasındaki yaratıcllı ve çoklu zekâ alanlarının araştıılması, Doktora tezi, Gazi Üniversitesi, Eğitim Bilimleri Enstitüsü.

Tok, E. ve Sevinç, M. (2010). Başarılı zekâ kuramına dayalı eğitim uygulamaları, Elektronik Sosyal Bilimler Dergisi, 9(32), 63-74.

Tok, E. (2008). Düşünme becerileri eğitimi programının okul öncesi öğretmen adaylartnın eleştirel, yaratıcı düşünme ve problem çözme becerilerine etkisinin incelenmesi, Doktora tezi, Marmara Üniversitesi, Eğitim Bilimleri Enstitüsü.

Topaktaş, A. (2001). Meslek lisesi öğrencilerinin yaratıcılık düzeylerinin değerlendirilmesi, Yüksek lisans tezi, Marmara Üniversitesi, Fen Bilimleri Enstitüsü.

Toyran, G. (2015). Okul öncesi öğretmen adaylarının yaratıcı düşünme düzeylerinin ve eleştirel düşünme eğilimlerinin bazı değişkenler açısından incelenmesi, Yüksek lisans tezi. Dokuz Eylül Üniversitesi, Eğitim Bilimleri Enstitüsü. 
Tuğrul, B. (2006). Okul öncesi dönemde düşünme becerilerinin gelişmesinde yaratıcı bir süreç olarak drama, Yaratııı Drama Dergisi, 1(2), 99-110.

Ülger, K. (2012). Öğrencilerin yaratıc düşünme becerileri ile problem çözme becerileri arasındaki ilişki, e-International Journal of Educational Research, 3(2), 50-62.

Üstündağ, T. (2014). Yaratıcliğga yolculuk, Ankara, Pegem Akademi

Yaman, S. ve Yalçın, N. (2005). Fen bilgisi öğretiminde probleme dayalı öğrenme yaklaşımının yaratıı düşünme becerisine etkisi, İlköğretim-Online, 4(1), 42-52.

Yavuzer, H. (1994). Yaratıcllk, İstanbul, Boğaziçi Üniversitesi Yayınları.

Yenilmez, K. ve Yolcu, B. (2007). Öğretmen davranışlarının yaratıcı düşünme becerilerinin gelişimine katkısı, Manas Üniversitesi Sosyal Bilimler Dergisi, 18, 95-105.

Yeşilyurt, E. (2013). Öğretmenlerin öğretim yöntemlerini kullanma amaçları ve karşılaştıkları sorunlar, Atatürk Üniversitesi Sosyal Bilimler Enstitüsü Dergisi, 17(1), 163-188.

Yeşilyurt, E. (2019a). Öğretim durumları modeli: Kuramsal temelleri bağlamında kapsamlı bir derleme çalışması, Turkish Studies Educational Sciences, 14(5), 2767-2785.

Yeşilyurt, E. (2019b). İşbirliğine dayalı öğrenme yöntemi: Tüm teknikleri kapsayıcı bir derleme çalışması, Turkish Studies Educational Sciences, 14(4), 1941-1970.

Yeşilyurt, E. (2019c). Kuramsal temelleri açısından öğretim stratejilerinin temel özellikleri: Bir derleme çalışması, Disiplinlerarası Eğitim Araştırmaları Dergisi, 3(5), 57-78.

Yeşilyurt, E. (2019d). Değerler eğitimine uygunluğu açısından öğretim yöntem ve tekniklerinin incelenmesi: Bir derleme çalışması, Ekev Akademi Dergisi, 23(77), 121-146

Yıldırım, E. (2007). Bilgi çağında yaratıcılığın ve yaratıclığı yönetmenin önemi, Selçuk Üniversitesi Karaman İ.I.B.F. Dergisi, 12(9), 109-120.

\section{Kaynakça Bilgisi / Citation Information}

Yeşilyurt, E. (2020). Yaratıcılık ve yaratıcı düşünme: Tüm boyut ve paydaşlarıyla kapsayıcı bir derleme çalışması. OPUS-Uluslararası Toplum Araştırmaları Dergisi, 15(25), 3874-3915. DOI: 10.26466/opus.662721 